\title{
Rebalance of the RAAS axes: the therapeutic strategy of COVID-19?
}

\author{
Wenhui Huang ${ }^{1}$, Ying Meng ${ }^{1}$, Pingsheng $\mathrm{Wu}^{1}$, and $\mathrm{Xu} \mathrm{\textrm {Li } ^ { 1 }}$ \\ ${ }^{1}$ Southern Medical University Nanfang Hospital
}

May 26, 2020

\begin{abstract}
COVID-19 has been the biggest global health threat since world war II. Up to now, the novel coronavirus pneumonia epidemic has resulted in over 300 thousand deaths. Angiotensin-converting enzyme 2 (ACE2), the receptor of SARS-CoV-2, is also the key modulator of renin-angiotensin-aldosterone system (RAAS) axes, which regulates the inflammatory response to maintain internal environment balance. On the contrary, RAAS axes can also regulate the expression of ACE2 which may influence on the susceptibility of SARS-CoV-2. Furthermore, SARS-CoV-2 binds with ACE2 and subsequently down-regulates ACE2 expression, which may exacerbate the inflammatory response due to RAAS imbalance. In this review, we summarized pathogenesis and clinical characteristics of COVID-19 patients, and discussed the potential link between the RAAS axes imbalance and the susceptibility/progression of organ injury in COVID-19. Therefore, we speculate that rebalance of the RAAS axes is the preventive and therapeutic strategy of COVID-19.
\end{abstract}

\section{Abbreviations list:}

ACE Angiotensin converting enzyme

ACE2 Angiotensin converting enzyme-2

RAAS Renin-angiotensin-aldosterone system

Ang I Angiotensin I

Ang II Angiotensin II

AT1R Ang II receptor type 1 receptor

AT2R Ang II receptor type 2 receptor

Ang (1-7) Angiotensin (1-7)

MasR Mas receptor

MrgD MAS-related G protein-coupled receptor D

ACEI Angiotensin converting enzyme inhibitor

ARB Angiotensin receptor blocker

rhACE2 recombinant human ACE2

ADAM17 disintegrin and metalloprotease 17

TMPRSS2 transmembrane protease serine 2

SARS severe acute respiratory syndrome 
ALI Acute lung injury

ARDS Acute respiratory distress syndrome

CNS Central nervous system

COVID-19 Coronavirus disease-19

IBD Inflammatory bowel disease

LPS lipopolysaccharide

eNOS endothelial nitric oxide synthase

\section{Introduction}

Since the start of the latest coronavirus (SARS-CoV-2) outbreak, the number of asymptomatic infected individuals and cases of coronavirus disease (COVID-19) have been increasing exponentially worldwide, which has been the biggest global health threat after world war II. COVID-19 is like to severe acute respiratory syndrome and mainly affects the respiratory tract and can subsequently result in acute respiratory distress syndrome (ARDS) and multi-organ failure(Huang et al. , 2020). Studies have proved that SARS-CoV-2, like SARS-CoV, is a family member of beta coronaviruses(Wang et al. , 2020) and 96\% identical at the wholegenome level to a bat coronavirus(Zhou et al. , 2020). Meanwhile, the SARS-CoV-2 virus has been reported that it uses angiotensin converting enzyme-2 (ACE2) as a cellular entry receptor via the spike protein (S). The interesting thing is that SARS-CoV-2 binds ACE2 with higher affinity than SARS-CoV(Wrapp et al. , 2020), which meant that it is difficult to control. ACE2 is a key modulator of the renin-angiotensin-aldosterone system (RAAS), which is associated with blood pressure homeostasis, oxidative stress, vasoconstriction, fibrosis and inflammation(Turneret al. , 2002). The infection of SARS-CoV-2 may decrease the ACE2 expression and subsequently induce the inflammation in various organs. Moreover, accumulating evidence has demonstrated that ACE2 may be essential in the progression and clinical outcomes of COVID-19(Xuet al. , 2020). Therefore, we will review the role of ACE2 in various conditions, and discuss its potential implication in the susceptibility and progression of COVID-19.

\section{The infected organs and transmission in COVID-19 patients}

Pathology and clinical symptoms indicated that SARS-CoV-2 can do harm to multiple organs. Therefore, it is important to understand the possible infected organs and route of transmission of SARS-CoV-2. Report showed that SARS-CoV-2 has the higher aerosol and surface stability than SARS-CoV(van Doremalen et al. , 2020). The human-to-human viral transitions of the SARS-CoV-2, reported by the previous studies, occurs due to close contact with an infected person, exposed to coughing, sneezing, respiratory droplets or aerosols. These aerosols can penetrate the human body (lungs) via inhalation through the nose or mouth. Therefore, the World Health Organization (WHO) has suggested that the personal protective equipment and infection control guidelines should be based on the assumption that the primary mechanism of transmission is direct and indirect droplet spread.

Direct droplet spread is said to occur when respiratory particles greater than $5 \mathrm{um}$ in diameter make contact with the mucosal surface of a recipient(Wilson et al. ,2020). Direct droplets can enter the human respiratory system through air(Jiang et al. , 2020), which causes respiratory symptoms. COVID-19 patients with respiratory distress could produce high levels of aerosols secondary to cough, high airway pressures, minute volumes, altered secretions and basal collapse. When infected patients expel respiratory particles and someone would inhale them, and subsequently the SARS-CoV-2 would find a welcome home in the nose(Sungnak et al. , 2020). High-flow nasal oxygen would disperse a concentrated jet of aerosols, potentially spreading them over a further distance or into the alveoli. These particles could gain direct access to alveolar surface ACE2 receptors under suitable biological, physical and environmental conditions. If the immune system does not beat back SARS-CoV-2 during this initial phase, the virus then marches down the windpipe to attack the lungs, where it can turn deadly. Several reports have reported that occur within families(Chan et al. , 2020). After the SARS-CoV-2 enters into the blood, it would invade different organs by binding to ACE2 
receptor. Although the lungs are ground zero, the SARS-CoV-2 would reach to many organs including the heart, kidneys, gut, brain, blood vessels and reproductive system. Clinical trials have demonstrated that the infected patients not only have respiratory symptoms, but have kidney, brain, reproductive system, gut and liver injury. SARS-CoV-2 may enter different organs through the hematogenous transmission. Coronavirus invades the central nervous system (CNS) through the olfactory bulb(Bohmwald et al. , 2018). The retrospective, observational case series have reported the COVID-19 patients may appear neurologic manifestations(Chen et al. , 2020; Mao et al. , 2020), including central nervous system manifestations (dizziness, headache, seizure and so on), and peripheral nervous system manifestations (nerve pain, taste impairment, smell impairment and so on). Although the clinical manifestation of COVID-19 is dominated by respiratory symptoms, some patients have severe cardiovascular damage(Huang et al. , 2020; Wang et al. , 2020), which may be related to the distribution of ACE2 in heart tissue. At the same time, acute kidney injury could also be induced by the virus(Guan et al. , 2020; Huang et al. , 2020; Wang et al. ,2020), which may be related to cytokine storm resulting from respiratory symptoms. Moreover, the liver injury should not be ignored because abnormal liver enzymes in serum was found in the hospitalized patients(Liu et al. , 2020; Weber et al. , 2020; Xu et al. , 2020). Furthermore, the glycemic variability was associated with composite adverse outcomes and death in COVID-19 patients(Zhu et al. , 2020). Moreover, impairment of reproductive health induced by SARS-CoV-2 may be caused by high levels of cytokines resulted from respiratory symptoms(Wang et al. , 2020). These complications in various organ mainly demonstrated the transmission of virus in blood.

The respiratory droplets transmission is the main route of infection, while there is indirect droplet spread, including contact transmission and Fecal-Oral transmission. Although there is little reported about the contact transmission, it still an important way in infection. The contact transmission is mainly touched by a hand, which then contacts mucosal surfaces. The SARS-CoV-2 patients have found the presence of virus in tears and conjunctival secretions(Xia et al. , 2020), while a single-center cross-sectional study found the risk of infection on ocular surface is low(Zhang et al. , 2020). Meanwhile, the SARS-CoV-2 could be found in the nasal cavity. The Fecal-Oral transmission is also possible in COVID-19, as virus was noted in stools(Lin et al. , 2020; Tang et al. , 2020; Zhang et al. , 2020). At the same time, some patients appeared gastrointestinal symptoms including diarrhea, vomiting and abdominal pain during course of the disease(Jin et al. , 2020; Young et al. , 2020). This may be related to the virus that could be detected in Oral or saliva, subsequently infected along the digestive tract(Azzi et al. , 2020). Altogether, the transmission and the infected organs were displayed in Figure 1 and Table 1 .

\section{ACE2 is the modulator of RAAS}

Angiotensin-converting enzyme 2 (ACE2), the main active peptide of renin-angiotensin-aldosterone system (RAAS), is a homologue to the carboxypeptidase angiotensin-converting enzyme (ACE), which generates angiotensin II (Ang II). As the name of RAAS indicates, renin and angiotensin are two critical components forming the system. Renin is the first and rate-limiting step in the RAAS cascade, without the renin enzyme there are no angiotensin. Angiotensinogen is the precursor to all angiotensin and is converted via renin to form angiotensin I (Ang I). Under the physiological conditions, the protease renin cleaves angiotensinogen to generate Ang I, then ACE cleaves Ang I to Ang II, which contact with Ang II receptor type 1 receptor (AT1R) and Ang II receptor type 2 receptor (AT2R). The proinflammatory effects of Ang II are mediated through AT1R(Fleming et al. , 2006). Studies have shown that the ACE/ Ang II/ AT1R axis can induce vasoconstriction, hypertension, inflammation, proliferation and fibrosis, and $\mathrm{ACE}$ is the key enzyme in the regulation of Ang II production. However, in 2000, the homologue of ACE, ACE2 has been discovered that it negatively regulates the activated renin-angiotensin system by degrading Ang II to the heptapeptide angiotensin (1-7) (Ang (1-7)), which reacts with MAS receptor (MasR)(Rice et al. , 2004). There are various methods to regulate the balance between ACE/ Ang II/ AT1R axis and ACE2/Ang (1-7)/Mas, including recombinant human ACE2 (rhACE2), ACE inhibitors (ACEI) and angiotensin receptor blockers (ARBs). As reported, ACE2 has a strong affinity with Ang II type 1 and type 2 receptors, thus it has been identified as an important counter regulatory mechanism to the classic RAAS. ACE2 controls the pressor/depressor balance of the RAAS by i) converting angiotensin I to angiotensin (1-9), limiting the number of substrate 
available to generate angiotensin II, ii) converting angiotensin II to angiotensin (1-7), restricting angiotensin II stimulation of the AT1 receptor and iii) generation of angiotensin (1-7), which is capable of binding to its own receptor, Mas receptor to oppose the pressor actions of the AT1 receptor. The ACE2/Ang (1-7)/Mas receptor axis has been shown to play protective roles in numerous disease models including heart failure, hypertension, injury, fibrosis and metabolic syndrome(Mirabitoet al. , 2019). Upregulating ACE2 may transfer the balance of RAAS to the ACE2/Ang (1-7)/Mas axis for protection. Most available evidence supports a counter-regulatory role for Ang (1-7) by opposing many actions of Ang II on AT1R receptors, especially vasoconstriction, inflammation and proliferation. In addition, ACE2 also has been confirmed as an essential receptor for SARS coronavirus infections as well as a protective molecule against lethal lung failure in SARS(Liet al. , 2003). In fact, SARS receptor function of ACE2 is independent of its catalytic activities for Ang II degradation, whereas ACE2-mediated Ang II degradation is important for lung protection from SARS pathogenesis.

\section{ACE2 is expressed in various organs and plays an important role in organ injury secondary to COVID-19}

According to the latest clinical research, the infected patients not only have respiratory symptoms, but also have cardiovascular, digestive, central system, renal and other symptoms(Guan et al. , 2020). ACE2 is a type I integral membrane glycoprotein widely expressed in lung, heart, endothelium, kidneys, gastrointestinal tract and so on(Zouet al. , 2020). Based on the findings, the organs, which highly express ACE2, may be vulnerable to SARS-CoV-2 infection. The decrease of ACE2 expression may accelerate lung injury because ACE2 is a protective molecule of RAAS, which induce the inflammatory response and organ damage. Binding to the ACE2 receptor is a critical initial step for SARS-CoV-2 to entry into target cells. In the process of infection, it is likely to require two kinds of transmembrane proteases: ADAM17 metalloproteinase and TMPRSS2 transmembrane protease. ACE2 could be cut by ADAM17 metalloproteinase, which hinders the binding of virus and ACE2(Lambert et al. , 2005); while TMPRSS2 transmembrane protease is required to the process, assisting the combination of ACE2 and SARS-CoV-2(Iwata-Yoshikawa et al. , 2019). SARS-CoV-2 appears not only to gain the initial entry through ACE2 but also subsequently to down-regulate ACE2 expression, which leads to the immune response imbalance caused by ACE/Ang II/AT1R activation(Vaduganathan et al. , 2020). The down-regulation of ACE2 reduces the level of Ang (1-7), and subsequently increases the production of Ang II, which activates the RAAS and enhances inflammation. (Figure 2 )

\subsection{The respiratory system damaged in COVID-19}

The lung is the most preliminary target organ for SARS-Cov-2 infection, and pneumonia is the most common complication seen in COVID-19 patients with the occurrence of 79.1\%(Xie et al. , 2020). As reported, ARDS is one of the most severe complications in COVID-19 patients(Wanget al. , 2020). The down-regulation of ACE2 plays an important role in the pathogenesis of severe lung failure after SARS-CoV infection(Kuba et al. , 2005). Recent data showed that COVID-19 patients with COPD as coexisting disorder were more likely to progress into severe cases, which may be related with the decrease of ACE2. It has been reported that ACE2 exerted protective effects against multiple organs injury via degrading Ang II to Ang (1-7)(Kuba et al. , 2010). For example, ACE2 knockout mice showed severe ARDS-like injury pathology in the lungs comparing to the wild type controls. At the same time, the respiratory symptoms can be alleviated by the treatment of rhACE2 protein(Imai et al. , 2005). Meanwhile, a phase II clinical study found that the level of Ang II decreased rapidly in serum and Ang(1-7) increased after patients with ARDS treated with rhACE2(Khanet al. , 2017). Administration of rhACE2 could ameliorate H5N1-induced lung injury in mice(Zou et al. , 2014). Furthermore, previous studies of ACE insertion/deletion (I/D) polymorphism correlation with severity of ARDS in humans(Jerng et al. , 2006; Marshall et al. , 2002) and ACE inhibitors treatments in rodent ARDS(Raiden et al. , 2002) have suggested that the RAAS could have role in ARDS/acute lung injury (ALI). In addition to the treatment of rhACE2 and ACEI/ARB, Ang (1-7) also has a positive effect on the process. The ratio of ACE/ACE2 was positively correlated with the ARDS and Ang (1-7) could prevent the symptoms due to the increase of ACE2(Wösten-van et al. , 2011). Infusions of Ang (1-7) prevented rats from

acute lung lesions after oleic acid administration as seen through a decrease in lung edema, myeloperoxidase 
activity, histological lung injury score, and pulmonary vascular resistance(Klein et al. , 2013). The same results could be observed in a pulmonary injury model based on lipopolysaccharide (LPS)(Chen et al. , 2013). These results convincingly proved that ACE2 is protective against lung injury and upregulation of the ACE2/Ang (1-7) axis may be a therapeutic target for patients with COVID-19.

\subsection{The intestinal homeostasis disorder in COVID-19}

It was reported that many COVID-19 patients appeared gastrointestinal symptoms, like diarrhea, abdominal pain and vomiting(Guan et al. , 2020; Holshue et al. , 2020; Jin et al. , 2020). SARS-CoV-2 RNA not only exists in lung, but also in anal swabs and stool specimen(Tang et al. , 2020; Zhang et al. , 2020). ACE2 was confirmed to be expressed in gastrointestinal epithelial cells by sequencing, and it was positively correlated with gene expression related to virus release(Zhang et al. , 2020). Consequently, the gut may be the target of SARS-CoV-2. While the mechanism of gastrointestinal symptoms is not fully understood, current data indicated these histological changes could be caused by the infection of SARS-CoV-2, especially the downregulation of ACE2 in tissue. The down-regulation of ACE2 expression will lead to the imbalance of RAAS, which causing inflammation in digestive system. It was found that the level of serum Ang II increased in the infected patients(Liu et al. , 2020), who have obvious clinical manifestations, such as diarrhea and liver injury with raised enzymes. Nevertheless, no viral inclusion was observed in the liver. Many studies have shown that the RAAS is related with the gut inflammation and gut microbiota. Treatment with Ang II may alter selectively gut microbial communities, and induce pathological alterations in gut wall(Sharma et al. , 2019). Previous animal experiments have shown that the expression of ACE2 and Ang (1-7) play an essential role in the gastrointestinal inflammation. The study of Hashimoto has confirmed that transplantation of the altered microbiota from ACE2 mutant mice into germ-free wild-type hosts was able to transmit the increased propensity to develop severe colitis(Hashimotoet al. , 2012). ACE2 interacts with B0AT1 amino acid transporter, which is necessary for polarized surface expression of the transporter in intestinal epithelial cells, and subsequently reduces the levels of tryptophan and other large amino acids, which resulted in alterations in gut inflammation and gut microbiota. Furthermore, systemic ACE2 deficiency would synergize to adversely impact both the microbiome and gut barrier function(Duan et al. , 2019). Meanwhile, inhibition of ACE2 may reduce DSS-induced inflammatory bowel disease (IBD) of mouse(Chen et al. , 2020). Moreover, treatment of the ACEI is able to upregulate ACE2 expression in injured liver(Huang et al. , 2010). In clinical trials, the IBD patients together with ACEI/ARB exposure had fewer hospitalizations, operations and corticosteroid prescriptions compared to matched controls(Jacobs et al. , 2019). All the above evidences have demonstrated that activation of the ACE2/Ang (1-7)/Mas signaling pathway or inhibition of the ACE/Ang II/AT1R pathway may be important treatments for gastrointestinal inflammation. Therefore, the imbalance of RAAS caused by SARS-CoV-2 infection may has adverse effects on the gut inflammation and gut microbiota, and gut-liver axis, which may participate in the pathological process of COVID-19 patients with sepsis. We speculate that rebalance of RAAS restore the intestinal homeostasis.

\subsection{Cardiovascular system impairment in COVID-19}

Patients with COVID-19 may have higher risk to develop complications and progress into severe cases when having coronal heart disease(Huanget al. , 2020). Among the hospitalized patients infected SARSCoV-2, acute cardiac injury is one of the common complications. The cardiac injury found in COVID-19 patients may be at least partially attributed to the fluctuation of ACE2 expression. Former researches have proved that elevated cardiac and plasma Ang II levels were correlated with the heart contractility impairment after deletion of ACE2(Gurleyet al. , 2006; Yamamoto et al. , 2006). It was found that ACE2 has the potential possibility to remodel and regulate heart function because ACE2 knockout mice has severe cardiac dysfunction(Nakamura et al. , 2008). Knockout mice of ACE genes or treatment with AT1 receptor blockers reversed the cardiac phenotype in ACE2 knockout mice(Oudit et al. , 2007). Similarly, the agedependent cardiomyopathy in ACE2 knockout mice is likely mediated by Ang II-induced oxidative stress and inflammation through AT1 receptor by PI3K signaling. Meanwhile, the correlation between the activity of ACE2 in serum and the deterioration of heart failure has been confirmed(Goulter et al. , 2004). Especially, in the development from hypertension to heart failure, the decrease of serum of ACE2 activity suggested 
a selective biomarker of cardiac systolic dysfunction(Pan et al. , 2018). Further in vivo murine studies showed Ang II mediated loss of membrane-bound cardiomyocyte ACE2 correlated with the upregulation of TACE/ADAM 17 activity which was prevented by AT1 receptor blockade(Weber et al. , 1991). Cardiac fibroblasts and coronary endothelial cells also express ACE2 and TACE and this reciprocal relationship extends to these cell types as well(Mehta et al. , 2007). In addition to counterbalancing Ang II/AT1R axis, the involvement of Ang (1-7) in the action of ACE2 on regulating heart function has been demonstrated. It is reported that the ACE2/Ang (1-7)/MasR axis plays an importance role in the regulation of RAAS system(Patel et al. , 2016). Treatment with Ang (1-7) peptide has been shown to improve myocardial performance, cardiac remodeling, and even survival in rodent heart failure models(Abwainy et al. , 2016; Santos et al. , 2004). All these evidences have proved that the ACE2/Ang (1-7)/MasR axis plays a very important role in cardiovascular system. Consequently, the impairment of cardiac function in COVID-19 patients is related to the down-regulation of ACE2/Ang (1-7)/MasR axis, which implicates the rebalance of RAAS in the treatment of COVID-19 with cardiovascular system impairment.

\subsection{Acute kidney injury in COVID-19}

Acute kidney injury is one of the severe complications in COVID-19 patients(Huang et al. , 2020) because ACE2 is abundantly expressed in kidney and the activity of ACE2 is even higher in the renal cortex than renal medulla(Wysocki et al. , 2010). The prevalence of kidney impairment (hematuria, proteinuria and kidney dysfunction) in hospitalized COVID-19 patients was high(Cheng et al. , 2020). ACE2 highly expresses in renal tubular cells, Leydig cells and cells in seminiferous ducts by analyzing ACE2 expression on the online datasets(Fan et al. , 2020). The expression of ACE2 has been confirmed to be related with acute kidney injury and several models of chronic kidney disease induced by hypertension(Fang et al., 2013; Soler et al. , 2013). ACE2 has emerged as a protective molecule against kidney diseases(Oudit et al. , 2009). ACE2 knockout can lead to blood pressure rise, glomerular injury and renal fibrosis in diabetic mice(Liu et al. , 2017). Meanwhile, deletion of ACE2 leads to late-onset nephrotic glomerulosclerosis spontaneously(Ouditet al. , 2006). On the contrary, the increase of Ang II in the damaged renal tubules may be a possible mediator for further renal damage in human renal diseases. Ferrario found that ACE2 in renal cortex activity was significantly augmented in rats medicated with ACEI/ARB but not changed in the group which given the combination(Ferrario et al. , 2005). Furthermore, the high plasma levels of Ang (1-7) also have effects in the kidney. Ang (1-7) administration attenuated kidney injury without affecting blood glucose levels in Akita mice(Shi et al. , 2015). In addition, Ang (1-7) could ameliorated the renal injury of nephrectomized rats, and the combination of Ang (1-7) treatment alongside losartan exerted a superior effect to that of Ang (1-7) alone on regression of glomerulosclerosis(Xu et al. ,2013). The physiological effects reported for alamandine, the novel RAAS mediator, were similar to Ang (1-7), including vasodilation, anti-fibrosis, anti-inflammation and so on. The higher alamandine in plasma was associated with the renal size and functions(Paquette et al. , 2018). At the same time, alamandine level in plasma of patients was fluctuating and was related with chronic renal failure(Hrenak et al. , 2016). In conclusion, clinicians should pay attention to the risk of testicular lesions in patients of COVID-19.

\subsection{Central nervous system impairment in COVID-19}

The symptoms of SARS-CoV-2 infection usually appeared in the human respiratory system, while coronavirus infection has been associated with neurological manifestations. Upon nasal infection, coronavirus invades the central nervous system (CNS) through the olfactory bulb, causing inflammation and demyelination(Bohmwald et al. , 2018). For example, a retrospective case series of 214 patients has been analyzed that $25 \%$ patients have CNS manifestation: headache (13\%), dizziness (17\%), impaired consciousness $(8 \%)$ and so on, while they did not perform clearly electroencephalography (EEG) or cerebrospinal fluid (CSF) analysis(Mao et al. , 2020). Another retrospective study has confirmed the occurrence of CNS following COVID-19(Chen et al. , 2020). As a matter of fact, the evidence on the CNS involvement of COVID-19 is scarce but still worthy of more attentions, because the infection of SARS-CoV-2 may partially explain why some patients develop respiratory failure. The entry of SARS-CoV-2 into human host cells is mainly mediated by the cellular receptor ACE2, thus the CNS manifestation may be associated with the expression 
of ACE2 in brain. In K18-hACE2 (hACE2 expression was driven by K18 promoter) mice, the brain was a major target organ for SARS infection(McCray et al. , 2007). The virus entered the brain primary via the olfactory bulb resulting in rapid, transneuronal spread to other areas of the brain and finally induced the death of experimental animal(Netland et al. , 2008). Although it is limited to explore the occurrence of CNS following COVID-19, there are lots of evidences that have proved the function of ACE2 in brain injury or stroke. Accordingly, ACE2-deficient mice showed increased oxidative stress in the brain and autonomic dysfunctions compared to controls(Xia et al. , 2011). However, in a stroke model triggered by middle cerebral artery occlusion ACE2 overexpression in the brain resulted in a decreased stroke volume and improved neurological scores in mice(Chen et al. , 2014; Zheng et al. , 2014). Moreover, the human RAAS transgenic mice showed enhanced cerebral damage in experimental ischemia models which again could be prevented by additional transgenic expression of ACE2 in neurons(Zhenget al. , 2014). Further experiments have demonstrated an intracellular expression of ACE2 based on immunohistochemistry in different areas of the brain(Doobay et al. , 2007) and Ang (1-7) expression in primary neuronal cell culture from hypothalamic-brain stem areas(Gironacci et al. , 2013). Interestingly, it has been reported that in this brain region Ang (1-7) can be formed independent of Ang II processing(Pereira et al. , 2013). Using MAS antagonists, the authors revealed that ACE2 exerts its beneficial effects in ischemic brain injury by shifting the balance between Ang II and Ang (1-7) in favor of the latter, thereby reducing local reactive oxygen species production(Regenhardt et al. , 2013). Numerous reports showed that ACE2/Ang (1-7)/Mas axis has beneficial effects in brain injury(Bennionet al. , 2015; Bennion et al. , 2018; Jiang et al. , 2012). At the same time, the potential cerebroprotective effects of Ang (1-7) were also examined in a model of haemorrhagic stroke produced by intra-striatal injection of collagenase in normotensive rats(Delet al. , 1996). While neurological manifestations of COVID-19 have still explored, it is highly likely that some of these patients have the susceptibility due to the distribution of ACE2 on central nervous system.

\subsection{Hyperglycemia in COVID-19}

Although there is no related epidemiological study about the diabetes in COVID-19 patients, we speculate that the patients with diabetes may have worse prognosis. A retrospective study published in LANCET found that half of patients infected with COVID-19 were associated with chronic diseases(Chen et al. , 2020), mainly including diabetes, cardiovascular diseases and digestive system diseases. Meanwhile, another retrospective study has found that 64 patients $(46.4 \%)$ have more than one chronic diseases, while 14 patients (10.15\%) with diabetes(Wang et al. , 2020). A retrospective, multi-centered study of 7337 cases of COVID-19 in Hubei Province, China, showed that patients with type 2 diabetes required more medical interventions and had a significantly higher mortality $(7.8 \%$ versus $2.7 \%)$ and multiple organ injury than the non-diabetic individuals(Zhu et al. , 2020). Furthermore, they also suggested well-controlled blood glucose (glycemic variability within 3.9 to $10.0 \mathrm{mmol} / \mathrm{L}$ ) was associated with markedly lower mortality compared to individuals with poorly controlled blood glucose. In coincidence, the COVID-19 patients with diabetes occurred hyperglycemia frequently and have higher mortality than patients without diabetes among 1122 patients reported in the United States(Bode et al. , 2020). These evidences indicated diabetic patients are likely to develop into severe cases once infection of SARS-CoV-2 occurs. ACE2 modulated the expression of neutral amino acid transporter on the insulin secretion pancreatic $\beta$-cells and the growth of pancreatic islet cells(Kuba et al. , 2010). The diabetic mice model expressing human ACE2 increased in the production of insulin, while decreased in apoptosis of pancreatic islet(Lu et al. , 2014). Local and systemic Ang II levels were regulated by ACE2, which was reduced in diabetic tissues(Tikellis et al. , 2012). Moreover, the ratio of ACE/ACE2 was positively correlated with the systolic pressure, the fasting blood glucose level, serum creatine in the patients(Mizuiriet al. , 2008). However, ACE2-deficient mice showed impairments in islet dysfunction and abnormality in glucose tolerance(Bindom et al. , 2010). Moreover, Endogenous ACE2 seems to have an effect on the adaptive $\beta$-cells hyperinsulinemic response, as seen in a diet-induced diabetes type 2 model, in which $\beta$-cells mass and proliferation were significantly reduced in ACE2-/y mice compared with controls(Shoemakeret al. , 2015). Interestingly, treatment with rhACE2 prevented from diabetic nephrology(Tikellis et al. , 2003). These studies suggested the relationship between ACE2 expression and hyperglycemia, while it still needed to explore the mechanism that COVID-19 patients are more prone 
to hyperglycemia in the status of ACE2 down-regulation.

\subsection{Urogenital injury in COVID-19}

The NATURE has showed that the testosterone to luteinizing hormone ( $\mathrm{T}$ to $\mathrm{LH}$ ) ratio in 81 patients with COVID-19 was decreased in comparison with 100 age-matched healthy counterparts(Wang et al. , 2020). Serum T to LH ratio could be a potential marker of impairment of reproductive health by SARSCoV-2. They considered that high levels of cytokines following viral or bacterial infection, illness or injury can cause deterioration in spermatogenesis and steroidogenesis, adversely affecting fertility. In the same time, the other study has demonstrated that females were able to achieve viral clearance significantly earlier than males, while they also have found that the ACE2 expression in testes, accompany with the lungs and kidneys, was highest consulting in three independent databases(Shastri et al. , 2020). Using online datasets, Fan and colleagues clearly demonstrated that ACE2 is highly expressed in Leydig cells and cells of the seminiferous tubules in the human testis(Fan et al. , 2020). Interestingly, very little expression of ACE2 was found in ovarian tissue. Instead of the SARS-CoV-2, viruses such as HIV, hepatitis B and C, mumps and papilloma have been proved that they can cause viral orchitis and even lead to male infertility and testicular tumors(Feichtinger et al. , 1992; Poretsky et al. , 1995; Tessler et al. , 1987). Meanwhile, the testis autopsy specimens obtained from six patients who died of SARS-CoV showed that the virus could induce orchitis(Xu et al. , 2006). Surprisingly, SARS-CoV-2 particles could be found in the epithelial cells of testicular seminiferous tubules and Leydig cells, providing direct evidence of viral testicular damage(Fan et al. , 2020). Evidences have identified that ACE2 was highly expressed in human testis(Donoghue et al. , 2000; Harmer et al. , 2002; Tipniset al. , 2000), which suggested the testis has the potential possiblity to be infected by the SARS-CoV-2 virus. The combination of SARS-CoV-2 with these ACE2-positive cells provided a site for infection and caused severe alteration of testicular tissue. Therefore, the urogenital organs should be a significant concern when evaluating the prognosis of COVID-19.

\section{Therapeutic strategy of COVID-19 by rebalancing the RAAS axes}

There are several potential approaches to address ACE2-mediated COVID-19. On the one hand, selectively blocking the combination of S protein and ACE2 may be an effective route; On the other hand, rebalancing the RAAS axes may improve inflammation.

\subsection{Blocking the combination of S protein and ACE2}

Alanine scanning mutagenesis analysis was performed to identify determinants on ACE2 critical for SARS$\mathrm{CoV}$ infection. The researchers found that charged amino acids between residues 22 and 57 were important, K26 and D30, in particular(Han et al. , 2006). At the meanwhile, Matthew found that a novel ACE2 inhibitor, NAAE, is effective in blocking the SARS coronavirus spike protein-mediated cell fusion by a structure-based approach(Huentelman et al. , 2004). Based on the combination of S protein and ACE2 in COVID-19, the structures of full-length human ACE2 have been revealed for the first time, and the dimeric ACE2 can accommodate two S protein trimers in SARS-CoV-2(Yanet al. , 2020). After the discovery of structures of full-length human ACE2, one study has determined the key region in SARS-CoV-2 that is responsible for the interaction with human ACE2(Wang et al. , 2020). Moreover, Shang and his colleague confirmed that a four-residue motif (residues 482-485: Gly-Val-Glu-Gly) could change the interface of SARSCoV-2 RBM and ACE2, which may provide a potential target for intervention strategies(Shang et al. , 2020). According to these discoveries, researchers determined the Mpro and RdRp were the mainly target of infection by analyzing the RNA polymerase(Gao et al. , 2020; Jin et al. , 2020). Although it is the most fundamental method to block the combination of ACE2 and SARS-CoV, this method is time-consuming and costly. Meanwhile, it is difficult to predict the variation of coronavirus.

\subsection{Rebalancing the RAAS axes by rhACE2}

SARS-CoV-2 infection reduced ACE2 activity and increased the receptor consumption, further exacerbating pathophysiological changes, such as ACE/ACE2 ratio imbalance. Accordingly, there are several potential approaches to address ACE2-mediated COVID-19, including increases the expression and the activity of ACE2 
to regulate the imbalance of RAAS. The imbalance of RAAS may result in abnormal high blood pressure and further induce multiple organ damage. Activation of the ACE2/Ang (1-7)/MasR signaling pathway or inhibition of the ACE/Ang II/AT1R pathway may be alternative treatments for novel coronavirus. Treatment with rhACE2 is the direct approach to regulate the ACE2/Ang (1-7)/MasR axis. A few pilot clinical studies have been conducted using rhACE2 in ARDS, and sepsis. For example, Monteil found that clinical grade recombinant human soluble ACE2 can significantly block early stages of SARS-CoV-2 infections(Monteil et al. , 2020). In a pilot clinical trial (NCT01597635)(Khan et al. , 2017), patients with ARDS treated with rhACE2 exhibited decreased plasma Ang II and elevated plasma Ang (1-7). An additional pilot study (NCT101884051) investigated the effects of rhACE2 in pulmonary arterial hypertension which is found that the ACE2 activity reduced(Hemnes et al. , 2018). The pharmacokinetics and pharmacodynamics of soluble rhACE2 treatment in healthy volunteers showed increased Ang (1-7) with no effect on blood pressure and heart rate (NCT00886353)(Haschke et al. , 2013). These clinical trials showed treatment with rhACE2 may improve excessive inflammation via activation of the ACE2/Ang (1-7)/Mas signaling pathway. Interestingly, treatment with rhACE2 may be completed with SARS-Cov-2 for ACE2, thus reduced the susceptibility of ACE2 binding to the virus.

\subsection{Rebalancing the RAAS axes by ACEI/ARB}

In addition to the treatment with rhACE2, ACEI and ARB can inhibit the ACE/Ang II/AT1R axis, leading to alleviation of inflammation, fibrosis, hypertension and so on. Since ACEI/ARB treatment up-regulates ACE2 expression, there are some controversy about the treatment of ACEI/ARBs in the infected patients coexist with cardiovascular disease. Fang(Fanget al. , 2020) and Diaz(Diaz, 2020) both hypothesized patients treated with ACEI/ARBs are at higher risk for SARS-CoV-2 infection due to up-regulation of ACE2 induced by ACEI/ARB, which would enhance viral binding and uptake, while there is no scientific evidence to demonstrate their prediction. On the contrary, someone insisted that ACEI/ARB may be beneficial in COVID-19 therapy, because up-regulation of the ACE2/Ang (1-7)/Mas axis contributes to relieve excessive inflammation(Baiet al. , 2016; Igase et al. , 2005; Ishiyama et al. , 2004). A retrospective study found that continuous administration of ACEI in hospital can reduce the mortality and intubation rate of patients with common viral pneumonia(Henry et al. , 2018). However, ACEI was divided into water soluble (captopril and lisinopril) and liposoluble (fosinopril). Some studies found that only lipophilic ACEI can reduce mortality of pneumonia patients. Long term use of lipophilic perindopril can significantly reduce the risk of pneumonia in patients with stroke and hypertension, but also significantly reduce the risk of pneumonia in elderly patients with hypertension(Mortensenet al. , 2008). It may be related to the drug characteristics that lipophilic ACEI can inhibit the RAAS activity more effectively, theoretically help to rebuild the balance of RAAS. Meanwhile, use of ARBs can delay the progression of ARDS(Raiden et al. , 2002), which may play a role in inhibiting ACE/Ang II/AT1R axis activity and neutrophil activation. Recent findings also demonstrate that patients treated with ARB (Olmesartan) had increased secretion of urinary ACE2, likely from an upregulation mechanism, although unclear(Furuhashiet al. , 2015). A new study assessed the impact of ACEI and ARBs treatment on the severity and prognosis in 1128 COVID-19 patients with hypertension. In this multi-center study, they compared the mortality rate between ACEI/ARB group and non-ACEI/ARB group and subsequently found that patients treatment with ACEI/ARBs were associated with lower risk of all-cause mortality compared with ACE/ARB non-users among hospitalized COVID-19 patients(Zhang et al. , 2020). Meanwhile, the other smaller retrospective study noted that hypertensive COVID-19 patients receiving ACEI or ARB treatment had a lower rate of severe COVID-19 diseases, a trend toward reduced blood levels of Interleukin- 6 plus reduced viral load and increased counts of cytotoxic T cells(Menget al. , 2020). Furthermore, one preliminary study examined 28 patients with severe COVID-19 and 18 patients with mild disease, all of whom also had hypertension, ARB use could reduce the higher risk of severe COVID19 disease, morbidity and mortality, the result that contradicts the hypothesis that ACEI/ARB use is not benefit(Liu et al. , 2020).

Although there is no evidence to support the treatment with ACEI/ARBs could enhance the susceptibility of SARS-CoV-2, withdrawal of ACEI/ARB is not benefit for the patients with cardiovascular diseases. COVID19 is particularly severe in patients with underlying cardiovascular diseases(Guan et al. , 2020), and in many 
of these patients, active myocardial injury(Arentz et al. , 2020) and cardiomyopathy develop during the course of illness. Among patients with chronic symptomatic heart failure, withdrawal of quinapril resulted in a progressive decline in clinical status(Wang et al. , 2020). Meanwhile, among asymptomatic patients with heart failure with recovered left ventricular ejection fraction, withdrawal of RAAS inhibitors resulted in rapid relapse of dilated cardiomyopathy(Halliday et al. , 2019). These evidences show among COVID-19 patients with cardiovascular diseases may higher risks after withdrawal of ACEI/ARB. Several cardiology associations released an official statement regarding the treatment of ACEI/ARB for COVID-19 patients. Actually, for those high-risk patients, individualized treatment decisions regarding the maintenance of RAAS inhibitors that should be guided by the hemondynamic status, and clinical stability.

\subsection{Rebalancing the RAAS axes by Ang (1-7)}

Our previous studies showed that Ang (1-7) exerts inhibitory effects on inflammation and oxidation via activating the ACE2/Ang (1-7)/MasR axis and inhibiting the ACE/Ang II/AT1R axis(Cai et al. , 2016; Menget al. , 2015). Ang (1-7)-induced signaling have been clarified in several aspects. The increase in NO release is the most classic aspect related to the protective role of Ang (1-7) and includes calcium-independent pathways and the posttranslational regulation of endothelial nitric oxide synthase (eNOS)(Sampaio et al. , 2007). Ang (1-7) additionally decreases TGF- $\beta$ /NF-kB signaling, a key pathway in inflammation(Marcus et al. , 2013). For example, Ang (1-7) significantly attenuated the peritonitis-induced sepsis via suppressing inflammation and apoptosis(Tsai et al. , 2018). Meanwhile, upregulation the ACE2/Ang (1-7)/MasR axis could ameliorate sepsis-induced acute lung injury(Chen et al. ,2019). Furthermore, administration of Ang (1-7) significantly reduced the neutrophil recruitment and modulated the inflammation in $\operatorname{IBD}$ (Khajah et al. , 2017). Additionally, Ang (1-7) has been proved that pretreatment could attenuate the Ang II-induced renal injury via Mas receptor(Kim et al. , 2015). Furthermore, the loose interstitial fibrosis was presented in lung tissue of COVID-19 patient, indicated the clinician should pay more attention to the pulmonary fibrosis(Zhang et al. , 2020). In coincidence, Ang (1-7) also exerts protective effects against fibrosis. We found that Ang (1-7) alleviated pulmonary fibrosis by inhibiting NOX4-derived ROS-mediated RhoA/Rock pathway(Meng et al. , 2015). The similar effects could be found in liver fibrosis(Cai et al. , 2016). The above compelling evidence indicated that the Ang (1-7) may represent novel therapeutic approach in the treatment of COVID-19.

\subsection{Rebalancing the RAAS axes by alamandine}

Alamandine, a novel member of the RAAS, is similar to Ang (1-7), with one amino acid difference. Alamandine has an Ala which replaces Asp at position 1 of Ang (1-7)(Villela et al. , 2014). Alamandine binds to the Mas-related $\mathrm{G}$ protein-coupled receptor $(\mathrm{MrgD})$, which exerts anti-inflammation and anti-fibrosis via up-regulating of the ACE2/alamandine/MrgD axis(Huang et al. , 2020). Accumulating evidences have demonstrated the alamandine has a profound effect in many diseases, including cardiomyopathy, hypertension and so on(Oliveiraet al. , 2019; Paquette et al. , 2018). For example, administration of alamandine could alleviate the inflammation by decreasing the infiltration of neutrophils and regulating macrophage polarization(de Carvalho et al. , 2019). Meanwhile, alamandine protected rat from myocardial injury by inhibiting NF- $x$ B pathway(Songet al. , 2019). Moreover, alamandine produced endothelial-dependent vasorelaxation in aortic rings of mice and rats(Lautner et al. , 2013) and attenuated arterial remodeling(de Souza-Neto et al. , 2019). Interestingly, alamandine could attenuate hepatic fibrosis by regulating autophagy(Huang et al. , 2020). Furthermore, alamandine level is also detectable in human plasma and elevated in patients with chronic renal failure(Hrenak et al. , 2016). These experimental researches are not enough to support that alamandine could be a therapeutic approach, while the protective effects of alamandine should not be ignored.

\section{Summary}

According to above compelling evidences, we speculated that consumption of ACE2 would enhance the ACE/Ang II/AT1R axis but inhibit the ACE2/Ang (1-7)/MasR axis, which resulted in imbalance of RAAS, and thus increased the inflammatory response. Rebalancing the RAAS may be the therapeutic and preventive 
strategy for COVID-19 patients. Interventions for rebalancing the RAAS include the treatment of rhACE2, ACEI/ARB, Ang (1-7), alamandine and so on. These interventions may upregulate ACE2 expression, while there is no evidence to support the possibility of increasing the susceptibility of SARS-CoV-2. Nevertheless, the experimental findings have demonstrated that upregulating ACE2 may shift the balance of RAAS axes from ACE/Ang II/AT1R axis to the ACE2/Ang (1-7)/Mas axis. Meanwhile, lots of clinical trials have demonstrated rebalancing the RAAS does play a protective role in improvement of inflammation. Therefore, we discuss our current understanding about the role of ACE2 in organs injury secondary to the COVID19, explore the benefit effects of the ACE2/Ang (1-7)/Mas axis, and then make our point that rebalances the RAAS can be the therapeutic and preventive strategy. However, further investigation is required to demonstrate whether these experimental effects could be translated into clinical benefit.

\section{ACKONOWLEDGEMENTS}

This study was supported by research grants from the National Science Foundation of China (No. 81870068, No. 81873583).

\section{CONFLICT OF INTEREST}

The authors declare no conflicts of interest. 


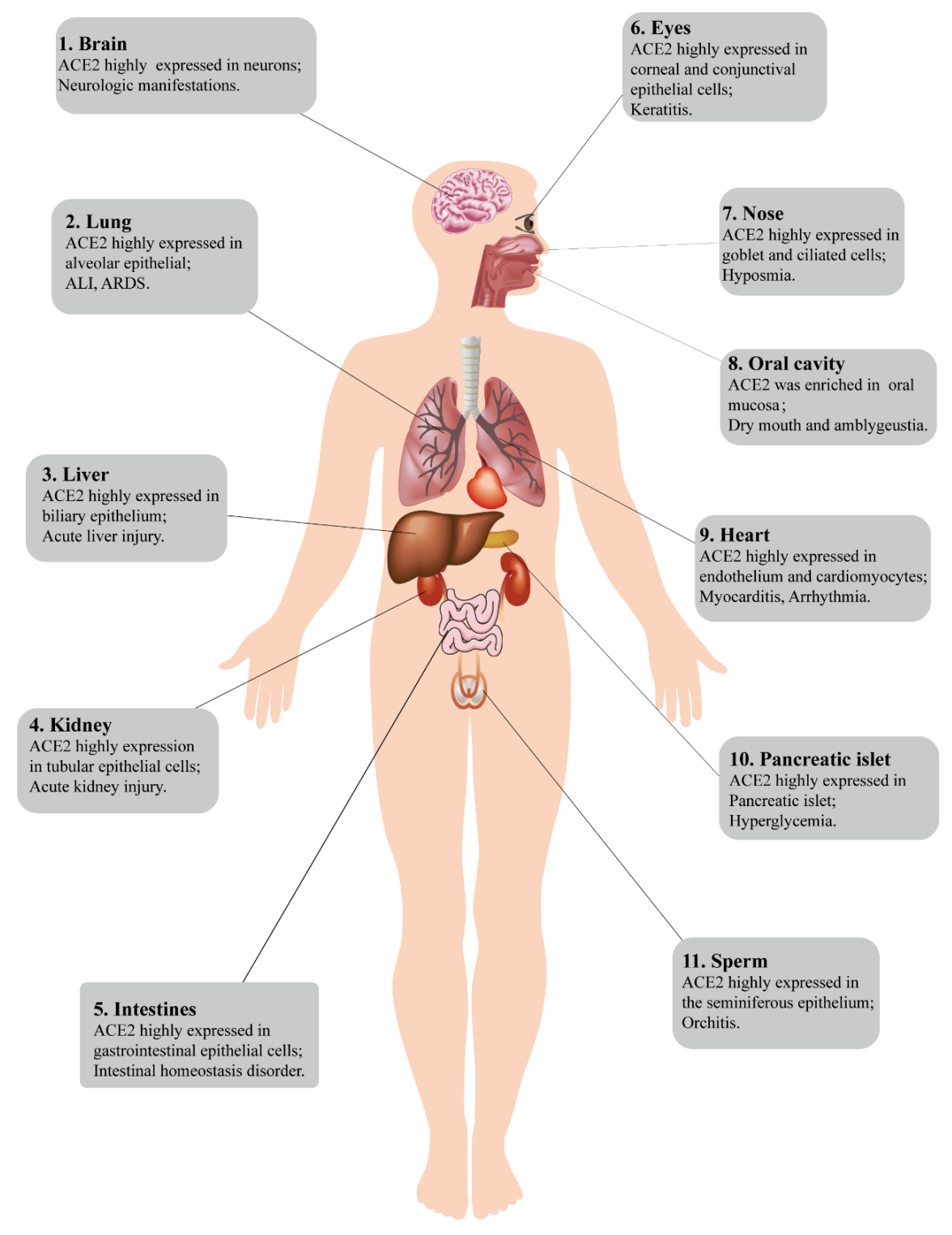

Figure 1 The systemic disorders caused by SARS-CoV-2 infection

Table 1 The infected organs and transmission in COVID-19 patients.

\begin{tabular}{|c|c|c|c|c|}
\hline Number & Transmission & Infected organ & Symptoms & Reference \\
\hline 1 & $\begin{array}{l}\text { Respiratory } \\
\text { droplets } \\
\text { transmission }\end{array}$ & Lung & $\begin{array}{l}\text { Dry cough, } \\
\text { Dyspnea, } \\
\text { Pharyngeal pain }\end{array}$ & $\begin{array}{l}\text { Huang et al., } \\
\text { 2020; Wang et al., } \\
2020\end{array}$ \\
\hline 2 & $\begin{array}{l}\text { Hematogenous } \\
\text { transmission }\end{array}$ & Heart & $\begin{array}{l}\text { Arrhythmia, Acute } \\
\text { cardiac injury }\end{array}$ & $\begin{array}{l}\text { Huang et al., 2020; } \\
\text { Wang et al., } 2020\end{array}$ \\
\hline 3 & $\begin{array}{l}\text { Hematogenous } \\
\text { transmission }\end{array}$ & Brain & $\begin{array}{l}\text { Headache, } \\
\text { Dizziness, Anorexia }\end{array}$ & $\begin{array}{l}\text { Chen et al., 2020; } \\
\text { Mao et al., } 2020\end{array}$ \\
\hline
\end{tabular}




\begin{tabular}{|c|c|c|c|c|}
\hline Number & Transmission & Infected organ & Symptoms & Reference \\
\hline 4 & $\begin{array}{l}\text { Hematogenous } \\
\text { transmission }\end{array}$ & Kidney & Proteinuria & $\begin{array}{l}\text { Guan et al., 2020; } \\
\text { Huang et al., } \\
2020 \text {; Wang et al., } \\
2020\end{array}$ \\
\hline 5 & $\begin{array}{l}\text { Hematogenous } \\
\text { route }\end{array}$ & Liver & $\begin{array}{l}\text { Abnormal liver } \\
\text { enzymes }\end{array}$ & $\begin{array}{l}\text { Liu et al., 2020; } \\
\text { Weber et al., } \\
2020 ; \text { Xu et al., } \\
2020\end{array}$ \\
\hline 6 & $\begin{array}{l}\text { Hematogenous } \\
\text { transmission }\end{array}$ & Pancreatic islet & $\begin{array}{l}\text { Glycemic } \\
\text { variability }\end{array}$ & Zhu et al., 2020 \\
\hline 7 & $\begin{array}{l}\text { Hematogenous } \\
\text { transmission }\end{array}$ & $\begin{array}{l}\text { Reproductive } \\
\text { system }\end{array}$ & $\begin{array}{l}\text { Serum } T \text { to } L H \\
\text { ratio decreased }\end{array}$ & Wang et al., 2020 \\
\hline 8 & $\begin{array}{l}\text { Contact } \\
\text { transmission }\end{array}$ & Eyes, nose & $\begin{array}{l}\text { virus in tears and } \\
\text { conjunctival } \\
\text { secretions }\end{array}$ & $\begin{array}{l}\text { Xia et al., 2020; } \\
\text { Zhang et al., } 2020\end{array}$ \\
\hline 9 & $\begin{array}{l}\text { Fecal-Oral } \\
\text { transmission }\end{array}$ & Intestine & $\begin{array}{l}\text { Diarrhea, } \\
\text { Vomiting, } \\
\text { Abdominal pain }\end{array}$ & $\begin{array}{l}\text { Lin et al., 2020; } \\
\text { Tang et al., 2020; } \\
\text { Zhang et al., } \\
\text { 2020; Jin et al., } \\
\text { 2020; Young et } \\
\text { al., 2020 }\end{array}$ \\
\hline 10 & $\begin{array}{l}\text { Fecal-Oral } \\
\text { transmission }\end{array}$ & Oral and saliva & $\begin{array}{l}\text { Dry mouth and } \\
\text { amblygeustia }\end{array}$ & Azzi et al., 2020 \\
\hline
\end{tabular}

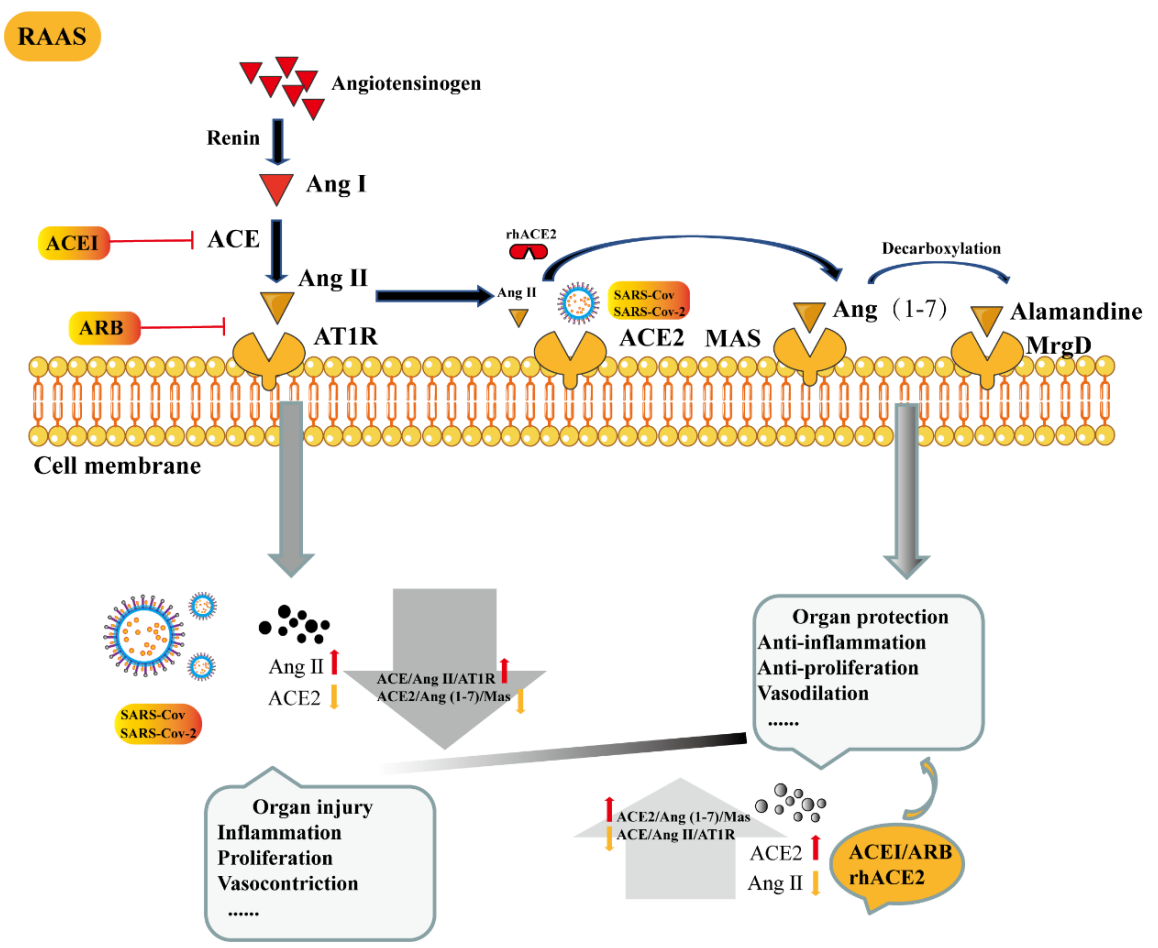

Figure 2 Diagram of renin-angiotensin- aldosterone system (RAAS) and the target of SARS- 


\section{Cov-2.}

In the diagram, there are two major axes in the RAAS: ACE/Ang II/AT1R axis and ACE2/Ang (1-7)/Mas axis; ACE2 is the key modulator in the RAAS, which plays a key importance in maintaining blood pressure homeostasis, containing fluid and salt balance in mammals. However, ACE2 is the receptor for SARS-Cov-2 infection which may lead to the imbalance of RAAS, and subsequently activate the inflammation in various organ.

\section{References:}

Abwainy, A, Babiker, F, Akhtar, S, Benter, IF (2016) Endogenous angiotensin-(1-7)/Mas receptor/NO pathway mediates the cardioprotective effects of pacing postconditioning. Am J Physiol Heart Circ Physiol 310 (1): H104-H112.

Arentz, M, Yim, E, Klaff, L, Lokhandwala, S, Riedo, FX, Chong, M, Lee, M (2020) Characteristics and Outcomes of 21 Critically Ill Patients With COVID-19 in Washington State. JAMA 323 (16): 1612-1614.

Azzi, L, Carcano, G, Gianfagna, F, Grossi, P, Gasperina, DD, Genoni, A, Fasano, M, Sessa, F, Tettamanti, L, Carinci, F, Maurino, V, Rossi, A, Tagliabue, A, Baj, A (2020) Saliva is a reliable tool to detect SARS-CoV-2. $J$ Infect .

Bai, F, Pang, XF, Zhang, LH, Wang, NP, McKallip, RJ, Garner, RE, Zhao, ZQ (2016) Angiotensin II AT1 receptor alters ACE2 activity, eNOS expression and CD44-hyaluronan interaction in rats with hypertension and myocardial fibrosis. LIFE SCI 153: 141-152.

Bennion, DM, Haltigan, E, Regenhardt, RW, Steckelings, UM, Sumners, C (2015) Neuroprotective mechanisms of the ACE2-angiotensin-(1-7)-Mas axis in stroke. CURR HYPERTENS REP 17 (2): 3.

Bennion, DM, Jones, CH, Donnangelo, LL, Graham, JT, Isenberg, JD, Dang, AN, Rodriguez, V, Sinisterra, R, Sousa, FB, Santos, R, Sumners, C (2018) Neuroprotection by post-stroke administration of an oral formulation of angiotensin-(1-7) in ischaemic stroke. EXP PHYSIOL103 (6): 916-923.

Bindom, SM, Hans, CP, Xia, H, Boulares, AH, Lazartigues, E (2010) Angiotensin I-converting enzyme type 2 (ACE2) gene therapy improves glycemic control in diabetic mice. DIABETES 59 (10): 2540-2548.

Bode, B, Garrett, V, Messler, J, McFarland, R, Crowe, J, Booth, R, Klonoff, DC (2020) Glycemic Characteristics and Clinical Outcomes of COVID-19 Patients Hospitalized in the United States. J Diabetes Sci Technol : 375611339 .

Bohmwald, K, Gálvez, N, Ríos, M, Kalergis, AM (2018) Neurologic Alterations Due to Respiratory Virus Infections. FRONT CELL NEUROSCI 12: 386.

Cai, SM, Yang, RQ, Li, Y, Ning, ZW, Zhang, LL, Zhou, GS, Luo, W, Li, DH, Chen, Y, Pan, MX, Li, X (2016) Angiotensin-(1-7) Improves Liver Fibrosis by Regulating the NLRP3 Inflammasome via Redox Balance Modulation.Antioxid Redox Signal 24 (14): 795-812.

Chan, JF, Yuan, S, Kok, KH, To, KK, Chu, H, Yang, J, Xing, F, Liu, J, Yip, CC, Poon, RW, Tsoi, HW, Lo, SK, Chan, KH, Poon, VK, Chan, WM, Ip, JD, Cai, JP, Cheng, VC, Chen, H, Hui, CK, Yuen, KY (2020) A familial cluster of pneumonia associated with the 2019 novel coronavirus indicating person-to-person transmission: a study of a family cluster.LANCET 395 (10223): 514-523.

Chen, H, Xuan, B, Yan, Y, Zhu, X, Shen, C, Zhao, G, Ji, L, Xu, D, Xiong, H, Yu, T, Li, X, Liu, Q, Chen, Y, Cui, Y, Hong, J, Fang, J (2020) Profiling ACE2 expression in colon tissue of healthy adults and colorectal cancer patients by single-cell transcriptome analysis. medRxiv :2020-2022.

Chen, J, Zhao, Y, Chen, S, Wang, J, Xiao, X, Ma, X, Penchikala, M, Xia, H, Lazartigues, E, Zhao, B, Chen, Y (2014) Neuronal over-expression of ACE2 protects brain from ischemia-induced damage. NEUROPHARMACOLOGY 79: 550-558. 
Chen, N, Zhou, M, Dong, X, Qu, J, Gong, F, Han, Y, Qiu, Y, Wang, J, Liu, Y, Wei, Y, Xia, J, Yu, T, Zhang, X, Zhang, L (2020) Epidemiological and clinical characteristics of 99 cases of 2019 novel coronavirus pneumonia in Wuhan, China: a descriptive study. LANCET395 (10223): 507-513.

Chen, Q, Liu, J, Wang, W, Liu, S, Yang, X, Chen, M, Cheng, L, Lu, J, Guo, T, Huang, F (2019) Sini decoction ameliorates sepsis-induced acute lung injury via regulating ACE2-Ang (1-7)-Mas axis and inhibiting the MAPK signaling pathway. BIOMED PHARMACOTHER 115: 108971.

Chen, Q, Yang, Y, Huang, Y, Pan, C, Liu, L, Qiu, H (2013) Angiotensin-(1-7) attenuates lung fibrosis by way of Mas receptor in acute lung injury. J SURG RES 185 (2): 740-747.

Cheng, Y, Luo, R, Wang, K, Zhang, M, Wang, Z, Dong, L, Li, J, Yao, Y, Ge, S, Xu, G (2020) Kidney impairment is associated with in-hospital death of COVID-19 patients. medRxiv : 2020-2022.

de Carvalho, SM, Dutra, MF, Vago, JP, Lima, KM, Galvão, I, de Souza-Neto, FP, Morais, ESM, Oliveira, AC, de Oliveira, F, Gonçalves, R, Teixeira, MM, Sousa, LP, Dos, SR, Da, SR (2019) Angiotensin-(1-7) and Alamandine Promote Anti-inflammatory Response in Macrophages In Vitro and In Vivo.Mediators Inflamm 2019: 2401081.

de Souza-Neto, FP, Silva, M, Santuchi, MC, de Alcântara-Leonídio, TC, Motta-Santos, D, Oliveira, AC, Melo, MB, Canta, GN, de Souza, LE, Irigoyen, M, Campagnole-Santos, MJ, Guatimosim, S, Santos, R, Da, SR (2019) Alamandine attenuates arterial remodelling induced by transverse aortic constriction in mice. Clin Sci (Lond)133 (5): 629-643.

Del, BM, Yan, HJ, Buist, R, Peeling, J (1996) Experimental intracerebral hemorrhage in rats. Magnetic resonance imaging and histopathological correlates. STROKE 27 (12): 2312-2319, 2319-2320.

Diaz, JH (2020) Hypothesis: angiotensin-converting enzyme inhibitors and angiotensin receptor blockers may increase the risk of severe COVID-19.J TRAVEL MED .

Donoghue, M, Hsieh, F, Baronas, E, Godbout, K, Gosselin, M, Stagliano, N, Donovan, M, Woolf, B, Robison, K, Jeyaseelan, R, Breitbart, RE, Acton, S (2000) A novel angiotensin-converting enzyme-related carboxypeptidase (ACE2) converts angiotensin I to angiotensin 1-9. CIRC RES87 (5): E1-E9.

Doobay, MF, Talman, LS, Obr, TD, Tian, X, Davisson, RL, Lazartigues, E (2007) Differential expression of neuronal ACE2 in transgenic mice with overexpression of the brain renin-angiotensin system. Am J Physiol Regul Integr Comp Physiol 292 (1): R373-R381.

Duan, Y, Prasad, R, Feng, D, Beli, E, Li, CS, Longhini, A, Lamendella, R, Floyd, JL, Dupont, M, Noothi, SK, Sreejit, G, Athmanathan, B, Wright, J, Jensen, AR, Oudit, GY, Markel, TA, Nagareddy, PR, Obukhov, AG, Grant, MB (2019) Bone Marrow-Derived Cells Restore Functional Integrity of the Gut Epithelial and Vascular Barriers in a Model of Diabetes and ACE2 Deficiency. CIRC RES 125 (11): 969-988.

Fan, C, Li, K, Ding, Y, Lu, WL, Wang, J (2020) ACE2 Expression in Kidney and Testis May Cause Kidney and Testis Damage After 2019-nCoV Infection.medRxiv : 2020-2022.

Fang, F, Liu, GC, Zhou, X, Yang, S, Reich, HN, Williams, V, Hu, A, Pan, J, Konvalinka, A, Oudit, GY, Scholey, JW, John, R (2013) Loss of ACE2 exacerbates murine renal ischemia-reperfusion injury. PLOS ONE 8 (8): e71433.

Fang, L, Karakiulakis, G, Roth, M (2020) Are patients with hypertension and diabetes mellitus at increased risk for COVID-19 infection? Lancet Respir Med 8 (4): e21.

Feichtinger, H, Kaaya, E, Putkonen, P, Li, SL, Ekman, M, Gendelman, R, Biberfeld, G, Biberfeld, P (1992) Malignant lymphoma associated with human AIDS and with SIV-induced immunodeficiency in macaques. AIDS Res Hum Retroviruses 8 (3): 339-348.

Ferrario, CM, Jessup, J, Gallagher, PE, Averill, DB, Brosnihan, KB, Ann, TE, Smith, RD, Chappell, MC 
(2005) Effects of renin-angiotensin system blockade on renal angiotensin-(1-7) forming enzymes and receptors. KIDNEY INT 68 (5): 2189-2196.

Fleming, I, Kohlstedt, K, Busse, R (2006) The tissue renin-angiotensin system and intracellular signalling. Curr Opin Nephrol Hypertens15 (1): 8-13.

Furuhashi, M, Moniwa, N, Mita, T, Fuseya, T, Ishimura, S, Ohno, K, Shibata, S, Tanaka, M, Watanabe, Y, Akasaka, H, Ohnishi, H, Yoshida, H, Takizawa, H, Saitoh, S, Ura, N, Shimamoto, K, Miura, T (2015) Urinary angiotensin-converting enzyme 2 in hypertensive patients may be increased by olmesartan, an angiotensin II receptor blocker. AM J HYPERTENS 28 (1): 15-21.

Gao, Y, Yan, L, Huang, Y, Liu, F, Zhao, Y, Cao, L, Wang, T, Sun, Q, Ming, Z, Zhang, L, Ge, J, Zheng, L, Zhang, Y, Wang, H, Zhu, Y, Zhu, C, Hu, T, Hua, T, Zhang, B, Yang, X, Li, J, Yang, H, Liu, Z, Xu, W, Guddat, LW, Wang, Q, Lou, Z, Rao, Z (2020) Structure of RNA-dependent RNA polymerase from 2019-nCoV, a major antiviral drug target.bioRxiv : 2020-2023.

Gironacci, MM, Longo, CN, Goldstein, J, Cerrato, BD (2013) Neuromodulatory role of angiotensin-(1-7) in the central nervous system. Clin Sci (Lond)125 (2): 57-65.

Goulter, AB, Goddard, MJ, Allen, JC, Clark, KL (2004) ACE2 gene expression is up-regulated in the human failing heart. BMC MED 2: 19.

Guan, W, Ni, Z, Hu, Y, Liang, W, Ou, C, He, J, Liu, L, Shan, H, Lei, C, Hui, DS, Du, B, Li, L, Zeng, G, Yuen, K, Chen, R, Tang, C, Wang, T, Chen, P, Xiang, J, Li, S, Wang, J, Liang, Z, Peng, Y, Wei, L, Liu, Y, Hu, Y, Peng, P, Wang, J, Liu, J, Chen, Z, Li, G, Zheng, Z, Qiu, S, Luo, J, Ye, C, Zhu, S, Zhong, N (2020) Clinical characteristics of 2019 novel coronavirus infection in China. medRxiv : 2020-2022.

Gurley, SB, Allred, A, Le TH, Griffiths, R, Mao, L, Philip, N, Haystead, TA, Donoghue, M, Breitbart, RE, Acton, SL, Rockman, HA, Coffman, TM (2006) Altered blood pressure responses and normal cardiac phenotype in ACE2-null mice. J CLIN INVEST 116 (8):2218-2225.

Halliday, BP, Wassall, R, Lota, AS, Khalique, Z, Gregson, J, Newsome, S, Jackson, R, Rahneva, T, Wage, R, Smith, G, Venneri, L, Tayal, U, Auger, D, Midwinter, W, Whiffin, N, Rajani, R, Dungu, JN, Pantazis, A, Cook, SA, Ware, JS, Baksi, AJ, Pennell, DJ, Rosen, SD, Cowie, MR, Cleland, J, Prasad, SK (2019) Withdrawal of pharmacological treatment for heart failure in patients with recovered dilated cardiomyopathy (TRED-HF): an open-label, pilot, randomised trial. LANCET393 (10166): 61-73.

Han, DP, Penn-Nicholson, A, Cho, MW (2006) Identification of critical determinants on ACE2 for SARS-CoV entry and development of a potent entry inhibitor. VIROLOGY 350 (1): 15-25.

Harmer, D, Gilbert, M, Borman, R, Clark, KL (2002) Quantitative mRNA expression profiling of ACE 2, a novel homologue of angiotensin converting enzyme. FEBS LETT 532 (1-2): 107-110.

Haschke, M, Schuster, M, Poglitsch, M, Loibner, H, Salzberg, M, Bruggisser, M, Penninger, J, Krähenbühl, S (2013) Pharmacokinetics and pharmacodynamics of recombinant human angiotensin-converting enzyme 2 in healthy human subjects. CLIN PHARMACOKINET 52 (9): 783-792.

Hashimoto, T, Perlot, T, Rehman, A, Trichereau, J, Ishiguro, H, Paolino, M, Sigl, V, Hanada, T, Hanada, R, Lipinski, S, Wild, B, Camargo, SM, Singer, D, Richter, A, Kuba, K, Fukamizu, A, Schreiber, S, Clevers, H, Verrey, F, Rosenstiel, P, Penninger, JM (2012) ACE2 links amino acid malnutrition to microbial ecology and intestinal inflammation. NATURE487 (7408): 477-481.

Hemnes, AR, Rathinasabapathy, A, Austin, EA, Brittain, EL, Carrier, EJ, Chen, X, Fessel, JP, Fike, CD, Fong, P, Fortune, N, Gerszten, RE, Johnson, JA, Kaplowitz, M, Newman, JH, Piana, R, Pugh, ME, Rice, TW, Robbins, IM, Wheeler, L, Yu, C, Loyd, JE, West, J (2018) A potential therapeutic role for angiotensinconverting enzyme 2 in human pulmonary arterial hypertension. EUR RESPIR $J \mathbf{5 1}$ (6). 
Henry, C, Zaizafoun, M, Stock, E, Ghamande, S, Arroliga, AC, White, HD (2018) Impact of angiotensinconverting enzyme inhibitors and statins on viral pneumonia. Proc (Bayl Univ Med Cent) 31 (4):419-423.

Holshue, ML, DeBolt, C, Lindquist, S, Lofy, KH, Wiesman, J, Bruce, H, Spitters, C, Ericson, K, Wilkerson, S, Tural, A, Diaz, G, Cohn, A, Fox, L, Patel, A, Gerber, SI, Kim, L, Tong, S, Lu, X, Lindstrom, S, Pallansch, MA, Weldon, WC, Biggs, HM, Uyeki, TM, Pillai, SK (2020) First Case of 2019 Novel Coronavirus in the United States. N Engl J Med382 (10): 929-936.

Hrenak, J, Paulis, L, Simko, F (2016) Angiotensin A/Alamandine/MrgD Axis: Another Clue to Understanding Cardiovascular Pathophysiology. INT J MOL SCI 17 (7).

Huang, C, Wang, Y, Li, X, Ren, L, Zhao, J, Hu, Y, Zhang, L, Fan, G, Xu, J, Gu, X, Cheng, Z, Yu, T, Xia, J, Wei, Y, Wu, W, Xie, X, Yin, W, Li, H, Liu, M, Xiao, Y, Gao, H, Guo, L, Xie, J, Wang, G, Jiang, R, Gao, Z, Jin, Q, Wang, J, Cao, B (2020) Clinical features of patients infected with 2019 novel coronavirus in Wuhan, China. LANCET395 (10223): 497-506.

Huang, ML, Li, X, Meng, Y, Xiao, B, Ma, Q, Ying, SS, Wu, PS, Zhang, ZS (2010) Upregulation of angiotensinconverting enzyme (ACE) 2 in hepatic fibrosis by ACE inhibitors. Clin Exp Pharmacol Physiol37 (1): e1-e6.

Huang, Y, Li, Y, Lou, A, Wang, GZ, Hu, Y, Zhang, Y, Huang, W, Wang, J, Li, Y, Zhu, X, Chen, T, Lin, J, Meng, Y, Li, X (2020) Alamandine attenuates hepatic fibrosis by regulating autophagy induced by NOX4-dependent ROS. Clin Sci (Lond) 134 (7):853-869.

Huentelman, MJ, Zubcevic, J, Hernández, PJ, Xiao, X, Dimitrov, DS, Raizada, MK, Ostrov, DA (2004) Structure-based discovery of a novel angiotensin-converting enzyme 2 inhibitor. HYPERTENSION44 (6): 903-906.

Igase, M, Strawn, WB, Gallagher, PE, Geary, RL, Ferrario, CM (2005) Angiotensin II AT1 receptors regulate ACE2 and angiotensin-(1-7) expression in the aorta of spontaneously hypertensive rats. Am J Physiol Heart Circ Physiol 289 (3): H1013-H1019.

Imai, Y, Kuba, K, Rao, S, Huan, Y, Guo, F, Guan, B, Yang, P, Sarao, R, Wada, T, Leong-Poi, H, Crackower, MA, Fukamizu, A, Hui, CC, Hein, L, Uhlig, S, Slutsky, AS, Jiang, C, Penninger, JM (2005) Angiotensinconverting enzyme 2 protects from severe acute lung failure. NATURE436 (7047): 112-116.

Ishiyama, Y, Gallagher, PE, Averill, DB, Tallant, EA, Brosnihan, KB, Ferrario, CM (2004) Upregulation of angiotensin-converting enzyme 2 after myocardial infarction by blockade of angiotensin II receptors. HYPERTENSION $\mathbf{4 3}$ (5): 970-976.

Iwata-Yoshikawa, N, Okamura, T, Shimizu, Y, Hasegawa, H, Takeda, M, Nagata, N (2019) TMPRSS2 Contributes to Virus Spread and Immunopathology in the Airways of Murine Models after Coronavirus Infection. J VIROL93 (6).

Jacobs, JD, Wagner, T, Gulotta, G, Liao, C, Li, YC, Bissonnette, M, Pekow, J (2019) Impact of Angiotensin II Signaling Blockade on Clinical Outcomes in Patients with Inflammatory Bowel Disease. Dig Dis Sci64 (7): 1938-1944.

Jerng, JS, Yu, CJ, Wang, HC, Chen, KY, Cheng, SL, Yang, PC (2006) Polymorphism of the angiotensinconverting enzyme gene affects the outcome of acute respiratory distress syndrome. CRIT CARE MED34 (4): 1001-1006.

Jiang, T, Gao, L, Guo, J, Lu, J, Wang, Y, Zhang, Y (2012) Suppressing inflammation by inhibiting the NF$x \mathrm{~B}$ pathway contributes to the neuroprotective effect of angiotensin-(1-7) in rats with permanent cerebral ischaemia. Br J Pharmacol 167 (7):1520-1532.

Jiang, Y, Wang, H, Chen, Y, He, J, Chen, L, Liu, Y, Hu, X, Li, A, Liu, S, Zhang, P, Zou, H, Hua, S (2020) Clinical Data on Hospital Environmental Hygiene Monitoring and Medical Staff Protection during the Coronavirus Disease 2019 Outbreak. medRxiv : 2020-2022. 
Jin, X, Lian, JS, Hu, JH, Gao, J, Zheng, L, Zhang, YM, Hao, SR, Jia, HY, Cai, H, Zhang, XL, Yu, GD, $\mathrm{Xu}$, KJ, Wang, XY, Gu, JQ, Zhang, SY, Ye, CY, Jin, CL, Lu, YF, Yu, X, Yu, XP, Huang, JR, Xu, KL, Ni, Q, Yu, CB, Zhu, B, Li, YT, Liu, J, Zhao, H, Zhang, X, Yu, L, Guo, YZ, Su, JW, Tao, JJ, Lang, GJ, Wu, XX, Wu, WR, Qv, TT, Xiang, DR, Yi, P, Shi, D, Chen, Y, Ren, Y, Qiu, YQ, Li, LJ, Sheng, J, Yang, Y (2020) Epidemiological, clinical and virological characteristics of 74 cases of coronavirus-infected disease 2019 (COVID-19) with gastrointestinal symptoms. GUT .

Jin, Z, Du X, Xu, Y, Deng, Y, Liu, M, Zhao, Y, Zhang, B, Li, X, Zhang, L, Peng, C, Duan, Y, Yu, J, Wang, L, Yang, K, Liu, F, Jiang, R, Yang, X, You, T, Liu, X, Yang, X, Bai, F, Liu, H, Liu, X, Guddat, LW, Xu, W, Xiao, G, Qin, C, Shi, Z, Jiang, H, Rao, Z, Yang, H (2020) Structure of M(pro) from COVID-19 virus and discovery of its inhibitors. NATURE .

Khajah, MA, Fateel, MM, Ananthalakshmi, KV, Luqmani, YA (2017) Anti-inflammatory action of angiotensin 1-7 in experimental colitis may be mediated through modulation of serum cytokines/chemokines and immune cell functions. DEV COMP IMMUNOL 74: 200-208.

Khan, A, Benthin, C, Zeno, B, Albertson, TE, Boyd, J, Christie, JD, Hall, R, Poirier, G, Ronco, JJ, Tidswell, M, Hardes, K, Powley, WM, Wright, TJ, Siederer, SK, Fairman, DA, Lipson, DA, Bayliffe, AI, Lazaar, AL (2017) A pilot clinical trial of recombinant human angiotensin-converting enzyme 2 in acute respiratory distress syndrome. CRIT CARE21 (1): 234.

Kim, CS, Kim, IJ, Bae, EH, Ma, SK, Lee, J, Kim, SW (2015) Angiotensin-(1-7) Attenuates Kidney Injury Due to Obstructive Nephropathy in Rats. PLOS ONE 10 (11): e142664.

Klein, N, Gembardt, F, Supé, S, Kaestle, SM, Nickles, H, Erfinanda, L, Lei, X, Yin, J, Wang, L, Mertens, M, Szaszi, K, Walther, T, Kuebler, WM (2013) Angiotensin-(1-7) protects from experimental acute lung injury. CRIT CARE MED 41 (11): e334-e343.

Kuba, K, Imai, Y, Ohto-Nakanishi, T, Penninger, JM (2010) Trilogy of ACE2: a peptidase in the reninangiotensin system, a SARS receptor, and a partner for amino acid transporters. Pharmacol Ther 128 (1): $119-128$.

Kuba, K, Imai, Y, Rao, S, Gao, H, Guo, F, Guan, B, Huan, Y, Yang, P, Zhang, Y, Deng, W, Bao, L, Zhang, B, Liu, G, Wang, Z, Chappell, M, Liu, Y, Zheng, D, Leibbrandt, A, Wada, T, Slutsky, AS, Liu, D, Qin, C, Jiang, C, Penninger, JM (2005) A crucial role of angiotensin converting enzyme 2 (ACE2) in SARS coronavirus-induced lung injury. NAT MED11 (8): 875-879.

Lambert, DW, Yarski, M, Warner, FJ, Thornhill, P, Parkin, ET, Smith, AI, Hooper, NM, Turner, AJ (2005) Tumor necrosis factor-alpha convertase (ADAM17) mediates regulated ectodomain shedding of the severeacute respiratory syndrome-coronavirus (SARS-CoV) receptor, angiotensin-converting enzyme-2 (ACE2). $J$ BIOL CHEM 280 (34): 30113-30119.

Lautner, RQ, Villela, DC, Fraga-Silva, RA, Silva, N, Verano-Braga, T, Costa-Fraga, F, Jankowski, J, Jankowski, V, Sousa, F, Alzamora, A, Soares, E, Barbosa, C, Kjeldsen, F, Oliveira, A, Braga, J, Savergnini, S, Maia, G, Peluso, AB, Passos-Silva, D, Ferreira, A, Alves, F, Martins, A, Raizada, M, Paula, R, MottaSantos, D, Klempin, F, Pimenta, A, Alenina, N, Sinisterra, R, Bader, M, Campagnole-Santos, MJ, Santos, RA (2013) Discovery and characterization of alamandine: a novel component of the renin-angiotensin system. CIRC RES112 (8): 1104-1111.

Li, W, Moore, MJ, Vasilieva, N, Sui, J, Wong, SK, Berne, MA, Somasundaran, M, Sullivan, JL, Luzuriaga, K, Greenough, TC, Choe, H, Farzan, M (2003) Angiotensin-converting enzyme 2 is a functional receptor for the SARS coronavirus. NATURE 426 (6965): 450-454.

Lin, L, Jiang, X, Zhang, Z, Huang, S, Zhang, Z, Fang, Z, Gu, Z, Gao, L, Shi, H, Mai, L, Liu, Y, Lin, X, Lai, R, Yan, Z, Li, X, Shan, H (2020) Gastrointestinal symptoms of 95 cases with SARS-CoV-2 infection.GUT .

Liu, Y, Huang, F, Xu, J, Yang, P, Qin, Y, Cao, M, Wang, Z, Li, X, Zhang, S, Ye, L, Lv, J, Wei, J, Xie, 
T, Gao, H, Xu, K, Wang, F, Liu, L, Jiang, C (2020) Anti-hypertensive Angiotensin II receptor blockers associated to mitigation of disease severity in elderly COVID-19 patients.medRxiv : 2020-2023.

Liu, Y, Yang, Y, Zhang, C, Huang, F, Wang, F, Yuan, J, Wang, Z, Li, J, Li, J, Feng, C, Zhang, Z, Wang, L, Peng, L, Chen, L, Qin, Y, Zhao, D, Tan, S, Yin, L, Xu, J, Zhou, C, Jiang, C, Liu, L (2020) Clinical and biochemical indexes from $2019-\mathrm{nCoV}$ infected patients linked to viral loads and lung injury. SCI CHINA LIFE SCI 63 (3): 364-374.

Liu, Z, Huang, XR, Chen, HY, Fung, E, Liu, J, Lan, HY (2017) Deletion of Angiotensin-Converting Enzyme-2 Promotes Hypertensive Nephropathy by Targeting Smad7 for Ubiquitin Degradation. HYPERTENSION 70 (4): $822-830$.

Lu, CL, Wang, Y, Yuan, L, Li, Y, Li, XY (2014) The angiotensin-converting enzyme 2/angiotensin (1-7)/Mas axis protects the function of pancreatic $\beta$ cells by improving the function of islet microvascular endothelial cells. INT J MOL MED34 (5): 1293-1300.

Mao, L, Jin, H, Wang, M, Hu, Y, Chen, S, He, Q, Chang, J, Hong, C, Zhou, Y, Wang, D, Miao, X, Li, Y, $\mathrm{Hu}$, B (2020) Neurologic Manifestations of Hospitalized Patients With Coronavirus Disease 2019 in Wuhan, China.JAMA NEUROL .

Marcus, Y, Shefer, G, Sasson, K, Kohen, F, Limor, R, Pappo, O, Nevo, N, Biton, I, Bach, M, Berkutzki, T, Fridkin, M, Benayahu, D, Shechter, Y, Stern, N (2013) Angiotensin 1-7 as means to prevent the metabolic syndrome: lessons from the fructose-fed rat model. DIABETES62 (4): 1121-1130.

Marshall, RP, Webb, S, Bellingan, GJ, Montgomery, HE, Chaudhari, B, McAnulty, RJ, Humphries, SE, Hill, MR, Laurent, GJ (2002) Angiotensin converting enzyme insertion/deletion polymorphism is associated with susceptibility and outcome in acute respiratory distress syndrome. Am J Respir Crit Care Med 166 (5): 646-650.

McCray, PJ, Pewe, L, Wohlford-Lenane, C, Hickey, M, Manzel, L, Shi, L, Netland, J, Jia, HP, Halabi, C, Sigmund, CD, Meyerholz, DK, Kirby, P, Look, DC, Perlman, S (2007) Lethal infection of K18-hACE2 mice infected with severe acute respiratory syndrome coronavirus. J VIROL81 (2): 813-821.

Mehta, PK, Griendling, KK (2007) Angiotensin II cell signaling: physiological and pathological effects in the cardiovascular system. Am J Physiol Cell Physiol 292 (1): C82-C97.

Meng, J, Xiao, G, Zhang, J, He, X, Ou, M, Bi, J, Yang, R, Di W, Wang, Z, Li, Z, Gao, H, Liu, L, Zhang, G (2020) Renin-angiotensin system inhibitors improve the clinical outcomes of COVID-19 patients with hypertension. Emerg Microbes Infect 9 (1):757-760.

Meng, Y, Li, T, Zhou, GS, Chen, Y, Yu, CH, Pang, MX, Li, W, Li, Y, Zhang, WY, Li, X (2015) The angiotensin-converting enzyme 2/angiotensin (1-7)/Mas axis protects against lung fibroblast migration and lung fibrosis by inhibiting the NOX4-derived ROS-mediated RhoA/Rho kinase pathway.Antioxid Redox Signal 22 (3): 241-258.

Mirabito, CK, Bovée, DM, Danser, A (2019) The renin-angiotensin-aldosterone system and its therapeutic targets.EXP EYE RES 186: 107680.

Mizuiri, S, Hemmi, H, Arita, M, Ohashi, Y, Tanaka, Y, Miyagi, M, Sakai, K, Ishikawa, Y, Shibuya, K, Hase, H, Aikawa, A (2008) Expression of ACE and ACE2 in individuals with diabetic kidney disease and healthy controls. AM J KIDNEY DIS 51 (4): 613-623.

Monteil, V, Kwon, H, Prado, P, Hagelkrüys, A, Wimmer, RA, Stahl, M, Leopoldi, A, Garreta, E, Hurtado, DPC, Prosper, F, Romero, JP, Wirnsberger, G, Zhang, H, Slutsky, AS, Conder, R, Montserrat, N, Mirazimi, A, Penninger, JM (2020) Inhibition of SARS-CoV-2 Infections in Engineered Human Tissues Using ClinicalGrade Soluble Human ACE2.CELL . 
Mortensen, EM, Restrepo, MI, Copeland, LA, Pugh, JA, Anzueto, A (2008) Association of hydrophilic versus lipophilic angiotensin-converting enzyme inhibitor use on pneumonia-related mortality. AM J MED SCI336 (6): $462-466$.

Nakamura, K, Koibuchi, N, Nishimatsu, H, Higashikuni, Y, Hirata, Y, Kugiyama, K, Nagai, R, Sata, M (2008) Candesartan ameliorates cardiac dysfunction observed in angiotensin-converting enzyme 2-deficient mice.HYPERTENS RES 31 (10): 1953-1961.

Netland, J, Meyerholz, DK, Moore, S, Cassell, M, Perlman, S (2008) Severe acute respiratory syndrome coronavirus infection causes neuronal death in the absence of encephalitis in mice transgenic for human ACE2. J VIROL 82 (15): 7264-7275.

Oliveira, AC, Melo, MB, Motta-Santos, D, Peluso, AA, Souza-Neto, F, Da, SR, Almeida, J, Canta, G, Reis, AM, Goncalves, G, Cerri, G, Coutinho, D, Guedes, DJI, Guatimosim, S, Linhares, ND, Alenina, N, Bader, M, Campagnole-Santos, MJ, Santos, R (2019) Genetic deletion of the alamandine receptor MRGD leads to dilated cardiomyopathy in mice.Am J Physiol Heart Circ Physiol 316 (1):H123-H133.

Oudit, GY, Herzenberg, AM, Kassiri, Z, Wong, D, Reich, H, Khokha, R, Crackower, MA, Backx, PH, Penninger, JM, Scholey, JW (2006) Loss of angiotensin-converting enzyme-2 leads to the late development of angiotensin II-dependent glomerulosclerosis. AM J PATHOL168 (6): 1808-1820.

Oudit, GY, Imai, Y, Kuba, K, Scholey, JW, Penninger, JM (2009) The role of ACE2 in pulmonary diseasesrelevance for the nephrologist.Nephrol Dial Transplant 24 (5): 1362-1365.

Oudit, GY, Kassiri, Z, Patel, MP, Chappell, M, Butany, J, Backx, PH, Tsushima, RG, Scholey, JW, Khokha, R, Penninger, JM (2007) Angiotensin II-mediated oxidative stress and inflammation mediate the agedependent cardiomyopathy in ACE2 null mice. CARDIOVASC RES75 (1): 29-39.

Pan, X, Shao, Y, Wu, F, Wang, Y, Xiong, R, Zheng, J, Tian, H, Wang, B, Wang, Y, Zhang, Y, Han, Z, Qu, A, Xu, H, Lu, A, Yang, T, Li, X, Xu, A, Du J, Lin, Z (2018) FGF21 Prevents Angiotensin IIInduced Hypertension and Vascular Dysfunction by Activation of ACE2/Angiotensin-(1-7) Axis in Mice. CELL METAB 27 (6): 1323-1337.

Paquette, K, Fernandes, RO, Xie, LF, Cloutier, A, Fallaha, C, Girard-Bock, C, Mian, M, Lukaszewski, MA, Mâsse, B, El-Jalbout, R, Lapeyraque, AL, Santos, RA, Luu, TM, Nuyt, AM (2018) Kidney Size, Renal Function, Ang (Angiotensin) Peptides, and Blood Pressure in Young Adults Born Preterm. HYPERTENSION 72 (4): 918-928.

Patel, VB, Zhong, JC, Grant, MB, Oudit, GY (2016) Role of the ACE2/Angiotensin 1-7 Axis of the ReninAngiotensin System in Heart Failure. CIRC RES 118 (8): 1313-1326.

Pereira, MG, Souza, LL, Becari, C, Duarte, DA, Camacho, FR, Oliveira, JA, Gomes, MD, Oliveira, EB, Salgado, MC, Garcia-Cairasco, N, Costa-Neto, CM (2013) Angiotensin II-independent angiotensin-(1-7) formation in rat hippocampus: involvement of thimet oligopeptidase.HYPERTENSION 62 (5): 879-885.

Poretsky, L, Can, S, Zumoff, B (1995) Testicular dysfunction in human immunodeficiency virus-infected men. METABOLISM 44 (7): 946-953.

Raiden, S, Nahmod, K, Nahmod, V, Semeniuk, G, Pereira, Y, Alvarez, C, Giordano, M, Geffner, JR (2002) Nonpeptide antagonists of AT1 receptor for angiotensin II delay the onset of acute respiratory distress syndrome.J PHARMACOL EXP THER 303 (1): 45-51.

Regenhardt, RW, Desland, F, Mecca, AP, Pioquinto, DJ, Afzal, A, Mocco, J, Sumners, C (2013) Antiinflammatory effects of angiotensin-(1-7) in ischemic stroke. NEUROPHARMACOLOGY 71: 154-163.

Rice, GI, Thomas, DA, Grant, PJ, Turner, AJ, Hooper, NM (2004) Evaluation of angiotensin-converting enzyme (ACE), its homologue ACE2 and neprilysin in angiotensin peptide metabolism. BIOCHEM $J \mathbf{3 8 3}$ (Pt 1): 45-51. 
Sampaio, WO, Souza, DSR, Faria-Silva, R, Da, MML, Schiffrin, EL, Touyz, RM (2007) Angiotensin-(1-7) through receptor Mas mediates endothelial nitric oxide synthase activation via Akt-dependent pathways. HYPERTENSION 49 (1): 185-192.

Santos, RA, Ferreira, AJ, Nadu, AP, Braga, AN, de Almeida, AP, Campagnole-Santos, MJ, Baltatu, O, Iliescu, R, Reudelhuber, TL, Bader, M (2004) Expression of an angiotensin-(1-7)-producing fusion protein produces cardioprotective effects in rats. PHYSIOL GENOMICS17 (3): 292-299.

Shang, J, Ye, G, Shi, K, Wan, Y, Luo, C, Aihara, H, Geng, Q, Auerbach, A, Li, F (2020) Structural basis of receptor recognition by SARS-CoV-2.NATURE .

Sharma, RK, Yang, T, Oliveira, AC, Lobaton, GO, Aquino, V, Kim, S, Richards, EM, Pepine, CJ, Sumners, C, Raizada, MK (2019) Microglial Cells Impact Gut Microbiota and Gut Pathology in Angiotensin II-Induced Hypertension. CIRC RES 124 (5): 727-736.

Shastri, A, Wheat, J, Agrawal, S, Chaterjee, N, Pradhan, K, Goldfinger, M, Kornblum, N, Steidl, U, Verma, A, Shastri, J (2020) Delayed clearance of SARS-CoV2 in male compared to female patients: High ACE2 expression in testes suggests possible existence of gender-specific viral reservoirs. medRxiv : 2020-2024.

Shi, Y, Lo, CS, Padda, R, Abdo, S, Chenier, I, Filep, JG, Ingelfinger, JR, Zhang, SL, Chan, JS (2015) Angiotensin-(1-7) prevents systemic hypertension, attenuates oxidative stress and tubulointerstitial fibrosis, and normalizes renal angiotensin-converting enzyme 2 and Mas receptor expression in diabetic mice. Clin Sci (Lond)128 (10): 649-663.

Shoemaker, R, Yiannikouris, F, Thatcher, S, Cassis, L (2015) ACE2 deficiency reduces $\beta$-cell mass and impairs $\beta$-cell proliferation in obese C57BL/6 mice. Am J Physiol Endocrinol Metab309 (7): E621-E631.

Soler, MJ, Wysocki, J, Batlle, D (2013) ACE2 alterations in kidney disease. Nephrol Dial Transplant 28 (11):2687-2697.

Song, XD, Feng, JP, Yang, RX (2019) Alamandine protects rat from myocardial ischemia-reperfusion injury by activating JNK and inhibiting NF-xB. Eur Rev Med Pharmacol Sci 23 (15):6718-6726.

Sungnak, W, Huang, N, Bécavin, C, Berg, M, Queen, R, Litvinukova, M, Talavera-López, C, Maatz, H, Reichart, D, Sampaziotis, F, Worlock, KB, Yoshida, M, Barnes, JL (2020) SARS-CoV-2 entry factors are highly expressed in nasal epithelial cells together with innate immune genes. NAT MED .

Tang, A, Tong, ZD, Wang, HL, Dai, YX, Li, KF, Liu, JN, Wu, WJ, Yuan, C, Yu, ML, Li, P, Yan, JB (2020) Detection of Novel Coronavirus by RT-PCR in Stool Specimen from Asymptomatic Child, China. EMERG INFECT DIS 26 (6).

Tessler, AN, Catanese, A (1987) AIDS and germ cell tumors of testis. UROLOGY 30 (3): 203-204.

Tikellis, C, Johnston, CI, Forbes, JM, Burns, WC, Burrell, LM, Risvanis, J, Cooper, ME (2003) Characterization of renal angiotensin-converting enzyme 2 in diabetic nephropathy. HYPERTENSION41 (3): 392-397.

Tikellis, C, Pickering, R, Tsorotes, D, Du XJ, Kiriazis, H, Nguyen-Huu, TP, Head, GA, Cooper, ME, Thomas, MC (2012) Interaction of diabetes and ACE2 in the pathogenesis of cardiovascular disease in experimental diabetes.Clin Sci (Lond) 123 (8): 519-529.

Tipnis, SR, Hooper, NM, Hyde, R, Karran, E, Christie, G, Turner, AJ (2000) A human homolog of angiotensin-converting enzyme. Cloning and functional expression as a captopril-insensitive carboxypeptidase. J BIOL CHEM 275 (43): 33238-33243.

Tsai, HJ, Liao, MH, Shih, CC, Ka, SM, Tsao, CM, Wu, CC (2018) Angiotensin-(1-7) attenuates organ injury and mortality in rats with polymicrobial sepsis. CRIT CARE 22 (1): 269.

Turner, AJ, Hooper, NM (2002) The angiotensin-converting enzyme gene family: genomics and pharmacology. TRENDS PHARMACOL SCI23 (4): 177-183. 
Vaduganathan, M, Vardeny, O, Michel, T, McMurray, J, Pfeffer, MA, Solomon, SD (2020) Renin-AngiotensinAldosterone System Inhibitors in Patients with Covid-19. N Engl J Med 382 (17): 1653-1659.

van Doremalen, N, Bushmaker, T, Morris, DH, Holbrook, MG, Gamble, A, Williamson, BN, Tamin, A, Harcourt, JL, Thornburg, NJ, Gerber, SI, Lloyd-Smith, JO, de Wit, E, Munster, VJ (2020) Aerosol and Surface Stability of SARS-CoV-2 as Compared with SARS-CoV-1. N Engl J Med382 (16): 1564-1567.

Villela, DC, Passos-Silva, DG, Santos, RA (2014) Alamandine: a new member of the angiotensin family. Curr Opin Nephrol Hypertens 23 (2): 130-134.

Wang, D, Hu, B, Hu, C, Zhu, F, Liu, X, Zhang, J, Wang, B, Xiang, H, Cheng, Z, Xiong, Y, Zhao, Y, Li, Y, Wang, X, Peng, Z (2020) Clinical Characteristics of 138 Hospitalized Patients With 2019 Novel CoronavirusInfected Pneumonia in Wuhan, China. JAMA .

Wang, Q, Zhang, Y, Wu, L, Niu, S, Song, C, Zhang, Z, Lu, G, Qiao, C, Hu, Y, Yuen, KY, Wang, Q, Zhou, H, Yan, J, Qi, J (2020) Structural and Functional Basis of SARS-CoV-2 Entry by Using Human ACE2. CELL

Wang, S, Zhou, X, Zhang, T, Wang, Z (2020) The need for urogenital tract monitoring in COVID-19. NAT REV UROL .

Weber, KT, Brilla, CG (1991) Pathological hypertrophy and cardiac interstitium. Fibrosis and reninangiotensin-aldosterone system.CIRCULATION $\mathbf{8 3}$ (6): 1849-1865.

Weber, S, Mayerle, J, Irlbeck, M, Gerbes, AL (2020) Severe liver failure during SARS-CoV-2 infection. GUT

Wilson, NM, Norton, A, Young, FP, Collins, DW (2020) Airborne transmission of severe acute respiratory syndrome coronavirus-2 to healthcare workers: a narrative review. ANAESTHESIA .

Wösten-van, AR, Lutter, R, Specht, PA, Moll, GN, van Woensel, JB, van der Loos, CM, van Goor, H, Kamilic, J, Florquin, S, Bos, AP (2011) Acute respiratory distress syndrome leads to reduced ratio of ACE/ACE2 activities and is prevented by angiotensin-(1-7) or an angiotensin II receptor antagonist.J PATHOL $\mathbf{2 2 5}$ (4): 618-627.

Wrapp, D, Wang, N, Corbett, KS, Goldsmith, JA, Hsieh, C, Abiona, O, Graham, BS, McLellan, JS (2020) Cryo-EM Structure of the 2019-nCoV Spike in the Prefusion Conformation. bioRxiv : 2020-2022.

Wysocki, J, Ye, M, Rodriguez, E, González-Pacheco, FR, Barrios, C, Evora, K, Schuster, M, Loibner, H, Brosnihan, KB, Ferrario, CM, Penninger, JM, Batlle, D (2010) Targeting the degradation of angiotensin II with recombinant angiotensin-converting enzyme 2: prevention of angiotensin II-dependent hypertension. HYPERTENSION55 (1): 90-98.

Xia, H, Suda, S, Bindom, S, Feng, Y, Gurley, SB, Seth, D, Navar, LG, Lazartigues, E (2011) ACE2-mediated reduction of oxidative stress in the central nervous system is associated with improvement of autonomic function. PLOS ONE 6 (7): e22682.

Xia, J, Tong, J, Liu, M, Shen, Y, Guo, D (2020) Evaluation of coronavirus in tears and conjunctival secretions of patients with SARS-CoV-2 infection. J MED VIROL .

Xie, J, Tong, Z, Guan, X, Du B, Qiu, H (2020) Clinical Characteristics of Patients Who Died of Coronavirus Disease 2019 in China. JAMA Netw Open 3 (4): e205619.

Xu, C, Ding, W, Zhang, M, Gu, Y (2013) Protective effects of angiotensin-(1-7) administrated with an angiotensin-receptor blocker in a rat model of chronic kidney disease. Nephrology (Carlton)18 (12): 761-769.

Xu, J, Qi, L, Chi, X, Yang, J, Wei, X, Gong, E, Peh, S, Gu, J (2006) Orchitis: a complication of severe acute respiratory syndrome (SARS). BIOL REPROD $\mathbf{7 4}$ (2): 410-416. 
Xu, X, Chen, P, Wang, J, Feng, J, Zhou, H, Li, X, Zhong, W, Hao, P (2020) Evolution of the novel coronavirus from the ongoing Wuhan outbreak and modeling of its spike protein for risk of human transmission. $S C I$ CHINA LIFE SCI 63 (3): 457-460.

Xu, XW, Wu, XX, Jiang, XG, Xu, KJ, Ying, LJ, Ma, CL, Li, SB, Wang, HY, Zhang, S, Gao, HN, Sheng, JF, Cai, HL, Qiu, YQ, Li, LJ (2020) Clinical findings in a group of patients infected with the 2019 novel coronavirus (SARS-Cov-2) outside of Wuhan, China: retrospective case series.BMJ 368: m606.

Yamamoto, K, Ohishi, M, Katsuya, T, Ito, N, Ikushima, M, Kaibe, M, Tatara, Y, Shiota, A, Sugano, S, Takeda, S, Rakugi, H, Ogihara, T (2006) Deletion of angiotensin-converting enzyme 2 accelerates pressure overload-induced cardiac dysfunction by increasing local angiotensin II.HYPERTENSION 47 (4): 718-726.

Yan, R, Zhang, Y, Li, Y, Xia, L, Guo, Y, Zhou, Q (2020) Structural basis for the recognition of SARS-CoV-2 by full-length human ACE2.SCIENCE 367 (6485): 1444-1448.

Young, BE, Ong, S, Kalimuddin, S, Low, JG, Tan, SY, Loh, J, Ng, OT, Marimuthu, K, Ang, LW, Mak, TM, Lau, SK, Anderson, DE, Chan, KS, Tan, TY, Ng, TY, Cui, L, Said, Z, Kurupatham, L, Chen, MI, Chan, M, Vasoo, S, Wang, LF, Tan, BH, Lin, R, Lee, V, Leo, YS, Lye, DC (2020) Epidemiologic Features and Clinical Course of Patients Infected With SARS-CoV-2 in Singapore. JAMA 323 (15): 1488-1494.

Zhang, H, Kang, Z, Gong, H, Xu, D, Wang, J, Li, Z, Cui, X, Xiao, J, Meng, T, Zhou, W, Liu, J, Xu, H (2020) The digestive system is a potential route of 2019-nCov infection: a bioinformatics analysis based on single-cell transcriptomes. bioRxiv : 2020-2021.

Zhang, H, Zhou, P, Wei, Y, Yue, H, Wang, Y, Hu, M, Zhang, S, Cao, T, Yang, C, Li, M, Guo, G, Chen, X, Chen, Y, Lei, M, Liu, H, Zhao, J, Peng, P, Wang, CY, Du R (2020) Histopathologic Changes and SARSCoV-2 Immunostaining in the Lung of a Patient With COVID-19. ANN INTERN MED 172 (9): 629-632.

Zhang, P, Zhu, L, Cai, J, Lei, F, Qin, JJ, Xie, J, Liu, YM, Zhao, YC, Huang, X, Lin, L, Xia, M, Chen, MM, Cheng, X, Zhang, X, Guo, D, Peng, Y, Ji, YX, Chen, J, She, ZG, Wang, Y, Xu, Q, Tan, R, Wang, H, Lin, J, Luo, P, Fu, S, Cai, H, Ye, P, Xiao, B, Mao, W, Liu, L, Yan, Y, Liu, M, Chen, M, Zhang, XJ, Wang, X, Touyz, RM, Xia, J, Zhang, BH, Huang, X, Yuan, Y, Rohit, L, Liu, PP, Li, H (2020) Association of Inpatient Use of Angiotensin Converting Enzyme Inhibitors and Angiotensin II Receptor Blockers with Mortality Among Patients With Hypertension Hospitalized With COVID-19. CIRC RES .

Zhang, W, Du RH, Li, B, Zheng, XS, Yang, XL, Hu, B, Wang, YY, Xiao, GF, Yan, B, Shi, ZL, Zhou, $\mathrm{P}$ (2020) Molecular and serological investigation of 2019-nCoV infected patients: implication of multiple shedding routes.Emerg Microbes Infect 9 (1): 386-389.

Zhang, X, Chen, X, Chen, L, Deng, C, Zou, X, Liu, W, Yu, H, Chen, B, Sun, X (2020) The evidence of SARS-CoV-2 infection on ocular surface. OCUL SURF .

Zheng, J, Li, G, Chen, S, Bihl, J, Buck, J, Zhu, Y, Xia, H, Lazartigues, E, Chen, Y, Olson, JE (2014) Activation of the ACE2/Ang-(1-7)/Mas pathway reduces oxygen-glucose deprivation-induced tissue swelling, ROS production, and cell death in mouse brain with angiotensin II overproduction. NEUROSCIENCE 273: 39-51.

Zheng, JL, Li, GZ, Chen, SZ, Wang, JJ, Olson, JE, Xia, HJ, Lazartigues, E, Zhu, YL, Chen, YF (2014) Angiotensin converting enzyme $2 /$ Ang-(1-7)/mas axis protects brain from ischemic injury with a tendency of age-dependence. CNS NEUROSCI THER 20 (5):452-459.

Zhou, P, Yang, XL, Wang, XG, Hu, B, Zhang, L, Zhang, W, Si, HR, Zhu, Y, Li, B, Huang, CL, Chen, HD, Chen, J, Luo, Y, Guo, H, Jiang, RD, Liu, MQ, Chen, Y, Shen, XR, Wang, X, Zheng, XS, Zhao, K, Chen, QJ, Deng, F, Liu, LL, Yan, B, Zhan, FX, Wang, YY, Xiao, GF, Shi, ZL (2020) A pneumonia outbreak associated with a new coronavirus of probable bat origin. NATURE $\mathbf{5 7 9}$ (7798): 270-273.

Zhu, L, She, ZG, Cheng, X, Qin, JJ, Zhang, XJ, Cai, J, Lei, F, Wang, H, Xie, J, Wang, W, Li, H, Zhang, P, Song, X, Chen, X, Xiang, M, Zhang, C, Bai, L, Xiang, D, Chen, MM, Liu, Y, Yan, Y, Liu, M, Mao, W, Zou, 
J, Liu, L, Chen, G, Luo, P, Xiao, B, Zhang, C, Zhang, Z, Lu, Z, Wang, J, Lu, H, Xia, X, Wang, D, Liao, X, Peng, G, Ye, P, Yang, J, Yuan, Y, Huang, X, Guo, J, Zhang, BH, Li, H (2020) Association of Blood Glucose Control and Outcomes in Patients with COVID-19 and Pre-existing Type 2 Diabetes. CELL METAB .

Zou, X, Chen, K, Zou, J, Han, P, Hao, J, Han, Z (2020) Single-cell RNA-seq data analysis on the receptor ACE2 expression reveals the potential risk of different human organs vulnerable to 2019-nCoV infection. Front Med .

Zou, Z, Yan, Y, Shu, Y, Gao, R, Sun, Y, Li, X, Ju, X, Liang, Z, Liu, Q, Zhao, Y, Guo, F, Bai, T, Han, Z, Zhu, J, Zhou, H, Huang, F, Li, C, Lu, H, Li, N, Li, D, Jin, N, Penninger, JM, Jiang, C (2014) Angiotensinconverting enzyme 2 protects from lethal avian influenza A H5N1 infections. NAT COMMUN 5: 3594 .

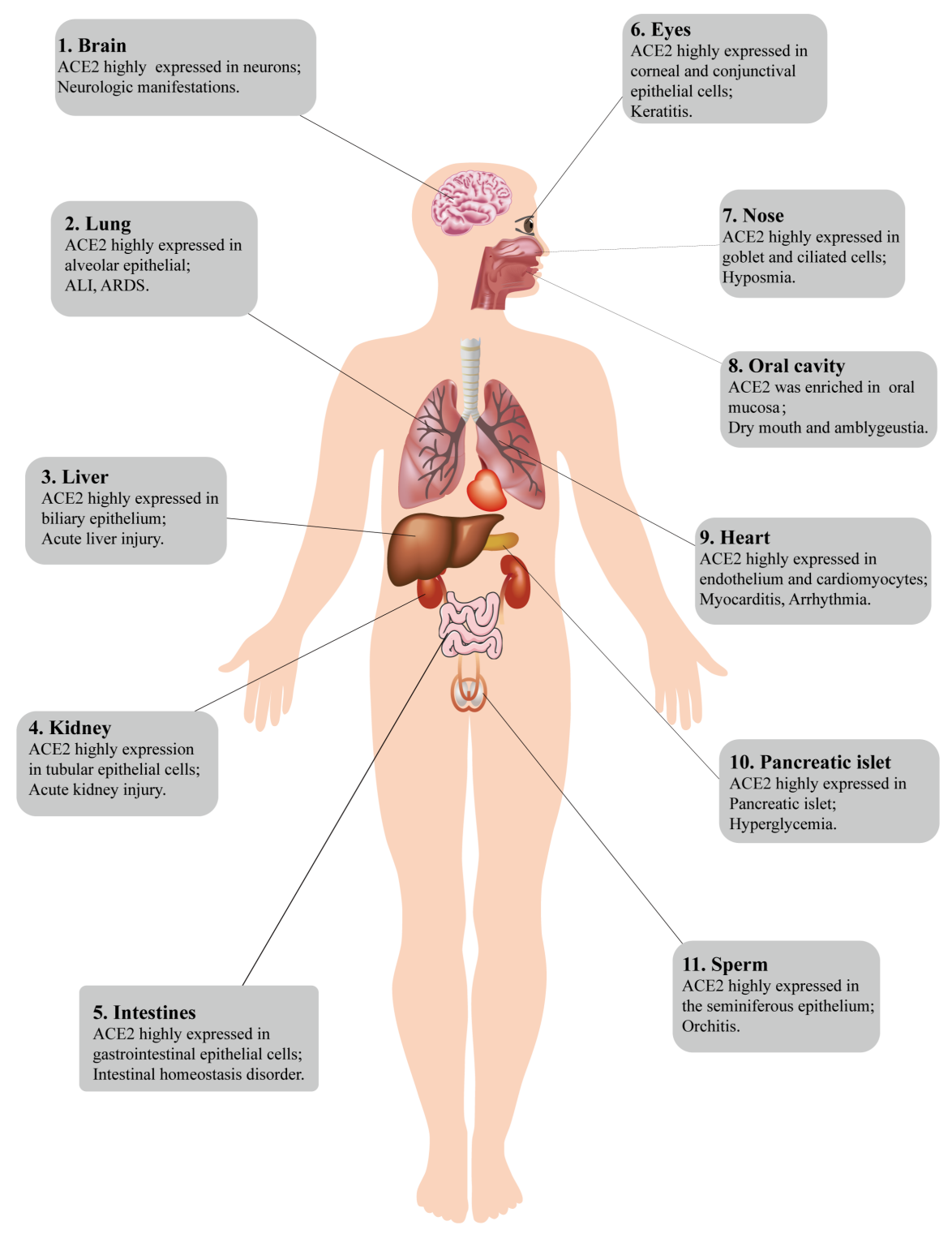

\section{Hosted file}

table 1.eps available at https://authorea.com/users/325864/articles/453869-rebalance-of-theraas-axes-the-therapeutic-strategy-of-covid-19 
RAAS

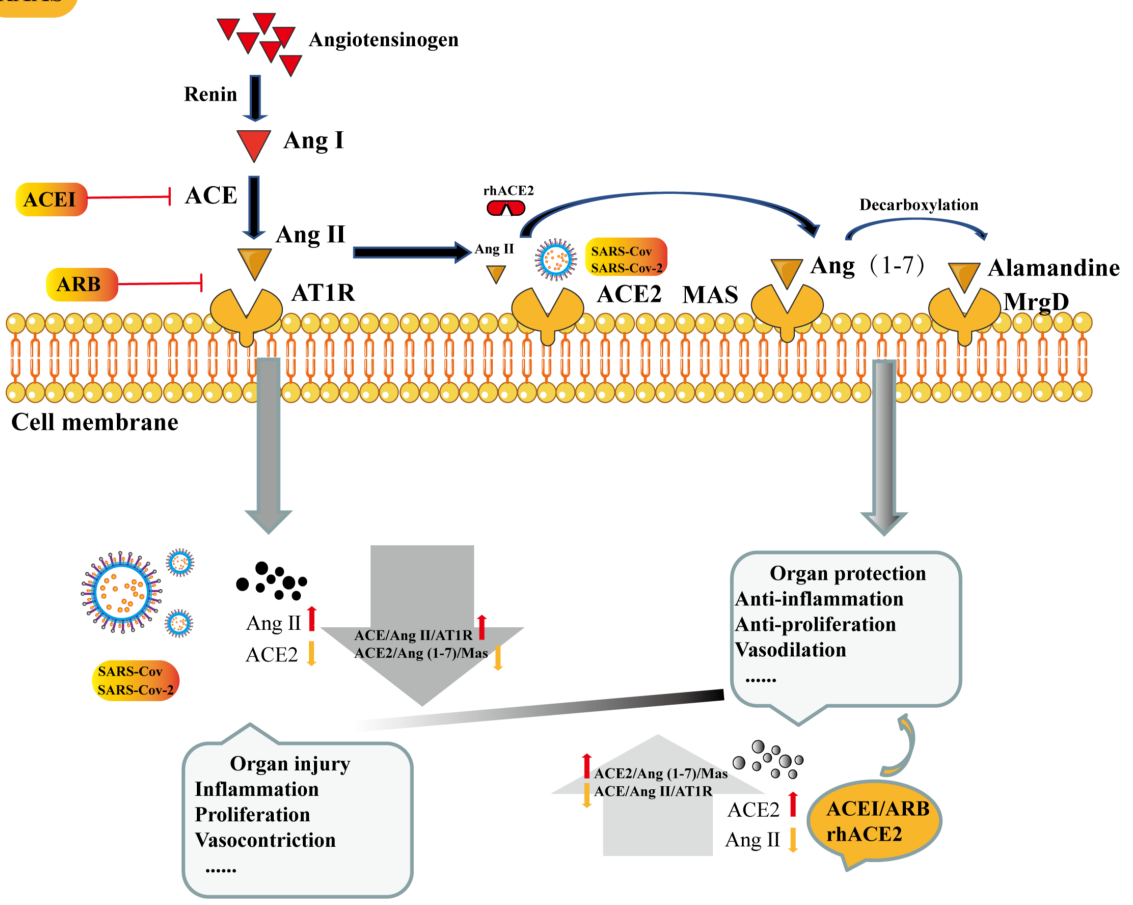

